\title{
Everyday Memory Measures in Multiple Sclerosis: A Systematic
}

\section{Review}

Roshan dasNair ${ }^{1,2 *}$, Holly Griffiths ${ }^{1}$, Sara Clarke ${ }^{1}$, Abigail Methley ${ }^{3}$, Ian Kneebone $^{4}$, \& Gogem Topcu ${ }^{1}$

${ }^{1}$ Division of Psychiatry and Applied Psychology, School of Medicine, University of Nottingham, Nottingham, United Kingdom

${ }^{2}$ Institute of Mental Health, University of Nottingham, Nottingham, United Kingdom

${ }^{3}$ Section for Clinical and Health Psychology, School of Psychological Sciences,

University of Manchester, Manchester, United Kingdom

${ }^{4}$ Discipline of Clinical Psychology, Graduate School of Health, University of Technology Sydney, Sydney, Australia

*Corresponding address: Prof Roshan dasNair, C22, Institute of Mental Health, Jubilee Campus, University of Nottingham, Nottingham NG7 2TU, UK

Phone: +44(0)115 8230589; Email: roshan.dasnair@nottingham.ac.uk 


\section{Everyday Memory Measures in Multiple Sclerosis: A Systematic}

\section{Review}

Everyday memory is one of the most affected cognitive functions in Multiple Sclerosis (MS). Assessing everyday memory problems is crucial for monitoring the impact of memory deficits on individuals' day-to-day lives and evaluating the effectiveness of interventions that aim to improve cognitive functions. The aim of this systematic review was to identify the research literature on everyday memory measures used with people with MS, describe the types of measures used, and summarise their psychometric properties. Empirical studies of cognitive function in MS using standardised everyday memory measures were included. Online databases (MEDLINE, PsycINFO, PsycARTICLES, Embase) and Google Scholar were searched. Forty-four studies met the inclusion criteria. A total of twelve measures were identified, with varied uses and administration methods. The majority of papers did not report any psychometric properties for MS populations. The few papers that did, reported that the measures have good reliability and appear to have good face, concurrent and ecological validity, but these need to be evaluated further. This review presents researchers and clinicians with an overview of the various everyday memory measures used in studies with people with MS, to help them choose the appropriate measure for their evaluations.

Keywords: everyday memory; multiple sclerosis; systematic review; psychometric properties

\section{Introduction}

Cognitive deficits affect up to $80 \%$ of individuals with Multiple Sclerosis (MS) (Fischer et al., 2014), with attention, memory, information processing, and executive functions being the most affected cognitive functions (Mackenzie, Morant, Bloomfield, MacDonald, \& O’Riordan, 2014; McIntosh-Michaelis et al., 1991; Rao, Leo, Bernardin, \& Unverzagt, 1991). Cognitive problems adversely affect individuals' activities of daily life, work, domestic, leisure and social activities, and cause distress and mood problems for the individual with MS, their family and carers (Feinstein, 2006; Gilchrist \& Creed, 
1994; Peyser, Rao, LaRocca, \& Kaplan, 1990).

Everyday memory refers to memory functions associated with daily life.

Examples include remembering names or faces, directions, shopping lists, locations of objects, future events or appointments. Tests of everyday memory have questionnaire items or activities that relate to, or closely resemble, routine everyday tasks. There is a variety of everyday memory measures available, most of which are subjective patientreported measures (Chipchase \& Lincoln, 2001; Sunderland, Harris \& Baddeley, 1983). Some 'objective' measures have also been developed to capture everyday memory (Rendell \& Craik, 2000; Smith, Della-Sala, Logie, \& Maylor, 2000; Wilson, Cockburn \& Baddeley, 1985; Wilson et al., 2005).

The assessment of everyday memory problems is important for monitoring the impact of memory deficits on an individual's daily life throughout disease progression and for evaluating the impact of interventions (e.g., memory rehabilitation) that aim to improve cognitive functions or help people cope with cognitive problems. Several trials of memory rehabilitation, however, have used impairment level measures of outcome, and not functional outcomes that map onto the International Classification of Functioning, Disability and Health's domains of activity limitation and participation restrictions, despite these domains being the focus of rehabilitation (World Health Organization, 2007). In a recent Cochrane review only five out of 15 trials that evaluated the effectiveness of memory rehabilitation in MS used subjective everyday memory measures, and most used list-learning tasks as objective memory assessments (das Nair, Martin, \& Lincoln, 2016).

To our knowledge, no systematic review has been conducted on everyday memory measures in MS (or any other clinical groups specifically), and this is the first systematic review examining the use of these measures with people with MS. 
Additionally, although the psychometric properties of the everyday memory measures have been adequately demonstrated for the general population or other clinical groups, we have a limited information with regards to their psychometric properties when used with people with MS.

Our aim, therefore, was to systematically review the research literature on everyday memory measures used with people with MS, describe the types of measures used, summarise their psychometric properties in relation to their use with people with MS, and describe how these measures have been used and what they have been used for. We believe this review may help clinicians and researchers choose the appropriate measures for their evaluations with people with MS.

\section{Methods}

A systematic search was conducted using the following electronic databases: Ovid MEDLINE (R), PsycINFO, PsycARTICLES and Embase, from their inception until 2nd May 2017. A search strategy was developed for Ovid MEDLINE (R) by two reviewers (A2 and A3) in consultation with a third reviewer (A1) [Author names removed to maintain the integrity of the review process]. Key words included: MS, disseminated sclerosis, multiple sclerosis; combined with everyday memory, daily memory, and real life memory. A two-step search process was used. First, an overview of everyday memory measures was compiled from the book A Compendium of Tests, Scales and Questionnaires (Tate, 2010). The name of each measure was combined with the above mentioned search terms. The search strategy for the everyday memory measures is available as supplementary material A. Second, where searches identified additional everyday memory measures used with samples of people with MS, these were then systematically searched in MEDLINE (2nd May 2017) and Google Scholar (24th February 2017). 
Papers obtained from the systematic search were independently screened by four reviewers (A2, A3, A4 and A6) [Author names removed to maintain the integrity of the review process]. Papers were initially screened by their titles and abstracts for eligibility. The fifth reviewer (A1) confirmed eligibility [Author name removed to maintain the integrity of the review process]. Eligibility of papers was determined according to the following inclusion criteria: (a) study participants had a diagnosis of any type of MS (relapsing-remitting, primary progressive, etc.); (b) participants were over the age of 16 years; (c) everyday memory of the person with MS was assessed (as outlined in the search strategy keywords) by the researcher/clinician, the individual with MS or their carer; (d) papers reported peer-reviewed empirical studies (excluding dissertations and protocols); (e) papers were available in English. Although measures such as the Perceived Deficits Questionnaire (PDQ; Sullivan, Edgley, \& DeHoux, 1990) can be used as a screening tool of cognitive functioning for studies on any topic, for this review we only considered studies using the PDQ where the focus of the study was everyday memory.

A paper was discarded if the abstract clearly did not meet the inclusion criteria or if it was a duplicate of another paper in the search results. Where the abstract provided insufficient detail, full texts were accessed.

Three reviewers (A2, A3 and A6) independently extracted data from the full texts. Any discrepancies were resolved through discussion, with another reviewer (A1) arbitrating where necessary [Author names removed to maintain the integrity of the review process]. All relevant data from the papers were entered onto a bespoke data extraction form (Supplementary material B) to enable final decisions regarding inclusion. We extracted the following data using a data extraction table (Supplementary material C): Publication details, study aims and methods, participant demographics, 
everyday memory measure used, how the measure was used, psychometric properties, and conclusions.

\section{Results}

\section{Characteristics of included studies}

The database searches produced a combined total of 1201 hits from which 44 papers were included in this review. These papers included studies from the UK $(1,4,7-11$, 26), Germany (2), Australia (3, 5, 12), USA (6, 13-21, 27, 33- 37, 39, 41, 43), Canada $(22,23,28,42,44)$, Italy (24), Finland (25, 31, 32), Iran (29), The Netherlands (30), Greece (38) and Spain (40). Sixteen studies used correlational designs (1, 3, 6, 7, 13, 14, $18,19,23,26,27,30,37-39,41)$, eleven had comparison group designs $(2,5,12,16$, 21, 22, 25, 28, 29, 35, 44). Eight studies were randomised controlled trials (4, 9, 11, 17 , $32,40,43)$, four were longitudinal $(24,34,36,42)$, two studies were quasi-experimental $(15,33)$, one study was an extension of another study $(31,32)$, one study used a retrospective design (8), one study used a survey design (10), and another was a longitudinal case study (20). See figure 1 for PRISMA flow diagrams for Ovid and Google Scholar searches (Moher, Liberati \& Tetzlaff, 2009).

Figure 1 here

\section{Characteristics of the samples}

In total, 4402 people with MS participated in these studies, and 17 studies also included healthy controls $(\mathrm{n}=779)(2,5,8,12,18,19,21,22,25,27-29,34,35,37,42,44)$. Some studies had mixed samples; three studies included informants $(n=368)(30,35$, 
37), two studies included people with stroke $(\mathrm{n}=107)(4,8)$, one included participants with traumatic brain injuries $(n=16)(4)$, and one included 51 carers of 51 people with MS (1).

\section{Demographics and illness characteristics of the samples}

The mean age of the MS participants ranged from 35.9 to 71 years old (SD range 6.4 to 13.78), with the youngest being 17 and oldest 84 years old $(8,44)$. Gender weightings in the sample were between $46 \%$ (21) to $100 \%$ women (20). Participants' educational level was variously coded in the studies. Thirty-six papers reported information on education and of these, only 27 papers reported the mean years of education of the participants ( 3 , $4-6,12-14,16,18,19,21-23,25-2731,32,34-37,40-44)$. The mean years of education ranged from 10.21 to 15.7 years for the overall sample (SD range 1.93 to 3.77). The other nine papers reported education in the following ways: 'levels' of formal education (2); the total number of participants within each education level $(17,23,33,30$,); age at which participants left education (16 years old; 9); percentages of the overall sample $(15,38)$; and the participants' highest qualification attained (20). Eight papers did not report this demographic characteristic $(1,7,8,10,11,24,29,39)$.

Only 25 papers reported participants' ethnicity, with $90 \%$ to $100 \%$ of the sample reported as 'Caucasian' in 10 papers (13, 15-18, 27, 33-35, 39). African-American people represented $3 \%$ to $14.3 \%$ in seven papers $(15,16-18,27,33,39)$, AmericanIndian represented $4 \%$ in one paper (27), and Hispanic people represented $1 \%$ to $5 \%$ of the overall sample in four papers $(15,16,18,27)$. Other ethnic minorities were simply described as 'other' in five papers $(15,16-18,33)$ with one paper using the term 'other' with the exception of Asian or Pacific Islander, Native American or Hispanic (39). Some participants had chosen not to provide details of their ethnicity and this was 
reported as 'declined' in one paper (27). Two papers reported some ethnicity categories but not others $(34,35)$.

Thirty-four papers specified the types of MS participants had, whereas ten did not report this $(1,4,5,8,10,17,29,33,38,44)$. Three studies had samples of participants with relapsing-remitting MS only $(20,31,32)$. Most papers had mixed samples with relapsing-remitting in 25 papers $(2,3,6,7,9,11,12,16,18,19,21,25$ $28,30,34-37,39-43)$, primary progressive in 22 papers $(2,3,6,7,9,11,14,16,19,22$, $27,28,30,34-37,39-43)$, secondary progressive in 26 papers $(3,6,9,11,13-16,18,19$, $21-23,26-28,30,34-37,39-43)$, progressive-relapsing in three papers $(27,35,41)$, clinically isolated syndrome in two papers $(28,30)$, and benign MS in one paper (11). Type of MS was unknown in four papers $(6,7,9,11)$ and defined as 'uncertain' in one paper (27).

\section{Characteristics of everyday measures}

There were 12 everyday measures identified in the 44 papers. In this section, we describe the types of measures used, why they were used, how they were administered, and the reported psychometric properties of these measures based on samples of people with MS, as described by the studies using these measures.

\section{Types of everyday measures}

The MS Neuropsychological Questionnaire (MSNQ; Benedict et al., 2003) was the most frequently used measure of everyday memory, used in 14 studies $(15,17,23,26$, 28, 30-35, 37, 40, 42). Six studies also used the MSNQ informant version (15, 23, 30, 31, 37, 42). Eight studies used the Perceived Deficits Questionnaire (17, 31, 32, 36, 38 , 39, 41, 44), and 6 studies used the Everyday Memory Questionnaire (EMQ; Sunderland et al., 1983) (1, 4, 8-11). Five studies used the Prospective and Retrospective Memory 
Questionnaire (PRMQ; Smith et al., 2000) (16, 18, 20, 22, 29). Four studies used the Memory Functioning Questionnaire (MFQ; Gilewski et al., 1990) $(6,14,15,43)$ and four used the Virtual Week task (Rendell et al., 2000) $(5,12,20,21)$. Three studies used the Rivermead Behavioural Memory Test (RBMT; Wilson et al., 1985) (2, 4, 24), one of which used its Extended version (Wilson et al., 1999) (4). Two studies used the Cognitive Failures Questionnaire (CFQ; Broadbent et al., 1982) $(7,19)$ and two used the Memory for Intentions Screening Test (MIST; Raskin, Buckeit \& Sherrod, 2010) $(16,27)$. The other tests used were the Cambridge Prospective Memory Test (CAMPROMT; Wilson et al., 2005) (3), the Memory Rating Scale (MRS; Rao, 1984) (13), and the Self-Evaluation of Everyday Memory and Learning Questionnaire (25). The scoring, administration, reliability and validity of the measures are presented in Table 1.

\section{Uses of everyday memory measures}

Eleven studies used everyday memory measures to correlate everyday memory with another measure of memory (e.g., another everyday memory measure, or other memory measures) $(6,13,15,18,19,30,35,36,39,41,42)$, and 12 studies used measures to correlate everyday memory with another variable (e.g., quality of life or mood) (13, 14, 18, 22-24, 27, 37-39, 41, 42). Everyday memory measures were also used as a predictor variable (e.g., for quality of life or carer strain) in five papers $(1,3,7,37,38)$ and a predicted variable in three papers $(19,27,34)$. In 23 studies, everyday memory measures were used to compare the difference in performance between groups (e.g., between people with MS and healthy controls) $(2,4,5,9,11,12,16,17,19,21,22,25$ 27, 29, 31, 32, 34-36, 40, 42, 43). Everyday memory measures were also used in seven studies as outcome measures in randomised controlled trials of memory rehabilitation $(4,9,11,17,21,31,32)$. Other uses of everyday memory measures were to classify 
people with MS as having impaired or unimpaired memory (10); to determine whether people with MS had over-estimated or underestimated their cognitive ability (35); to screen participants for eligibility into a trial $(17,28,33)$; or as part of a battery to describe memory deficits for a case study (20). Eight papers analysed the psychometric properties of an everyday memory measure $(8,15,23,30,34,35,37,44)$.

\section{Administration of Everyday Memory Measures}

Everyday memory measures were mostly administered face-to-face (see Table 1) or this was inferred from 27 papers $(2-5,9,12,14-16,18-24,26-28,31,32,34,35,37,40,42$, 43). They were also used as postal measures in seven studies $(1,4,7,10,11,30,39)$, or administered over the phone in two studies $(17,33)$. Only three papers explicitly reported that the measure was self-administered $(25,30,38)$ (we made an assumption in the absence of information in the paper that when used as a postal measure, the measure was self-administered). One paper posted the measure in a newsletter (44). Seven papers did not report how the everyday memory measures were administered $(6,8,13$, $17,29,36,41)$.

Table 1 here

\section{Psychometric properties of Everyday Memory Measures}

The following psychometric properties were reported for the reliability and validity of the everyday memory measures as described within the included studies that used these measures with samples of people with MS (see Table 2).

Of the six papers that used the EMQ, only one reported the internal consistency reliability (8). Cronbach's alpha was high (0.89) for the 13-item version of this scale. 
Two papers reported on its validity, both reporting 'good face validity' $(4,8)$. One paper assessed this by comparing the original scale with a 13-item revised scale, and also assessed the construct validity by comparing patients with memory problems with healthy participants (8).

Of the 14 papers that used the MSNQ, four reported on the internal consistency, with two only referring to it as 'reliable' (23), and having 'excellent internal consistency'(35), and another two papers reported Cronbach's alphas ranging from 0.93 to $0.95(17,30)$. Two papers reported on the interrater reliability, with one paper referring to it as 'moderate' with an intraclass correlation coefficient of -0.59 (95\% 0.49 $-0.69)$, along with low to moderate weighted kappa values for item scores $(0.25-0.50)$ (30). Another paper reported correlation scores between MSNQ-Self report and MSNQInformant report scores $(\mathrm{r}=.55, \mathrm{p}<.01)(37)$. Two papers reported on the test-retest reliability; Cronbach's alpha ranged from 0.86 to 0.90 for one of the papers (34), whereas the other paper referred only to the measure having 'excellent test-retest reliability' (35).

Validity was reported by five papers. Construct validity was reported in one paper by testing six hypotheses by calculating Spearman correlations between the MSNQ-P (self-report) and MSNQ-Informant report, an observational measure of memory and measures of anxiety and depression (correlations ranged from $0.26-0.49$ ) (30). One study assessed construct validity via regression and reported R2 values ranged from $0.28-0.40$ and reported that two combined measures (the Symbol Digits Modalities Test (SDMT; Smith et al., 1982) and the Beck Depression Inventory Fast Screen (BDIFS; Benedict et al., 2003) accounted for a third of the variance in the MSNQ (34). One study assessed the validity of the MSNQ discrepancy scores in all MS patients who had either under-, over-, or accurately estimated neuropsychological 
impairment, and then in a subgroup of cognitively impaired patients (35). This paper reported discrepancy scores ranging from $16-30(\mathrm{M}=21.1, \mathrm{SD}=3.6)$ in the underestimator group, $-4-11(\mathrm{M}=2.4, \mathrm{SD}=4.2)$ in the accurate estimator group, and $-37-$ $11(\mathrm{M}=-20.6, \mathrm{SD}=7.4)$ in the over-estimator group. For MS patients categorised as 'cognitively impaired', discrepancy scores ranged from $16-30(\mathrm{M}=20.6, \mathrm{SD}=4.3)$ in the under-estimator group, $-3-10(\mathrm{M}=2.5, \mathrm{SD}=4.0)$ in the accurate estimator group, and $-37--11(\mathrm{M}=-20.4, \mathrm{SD}=7.5)$ in the over-estimator group (35). The fourth paper reported MSNQ sensitivity as $.52(95 \%$ confidence interval $[\mathrm{CI}] .32-.72)$ and specificity as $0.70(95 \% \mathrm{CI} .51-.82)$ when categorising patients in the 'global cognitive impairment categories' (37). With a cut-off score of 24 on the MSNQ, only $62 \%$ of the MS patients were correctly categorised as either impaired or not impaired. A cut-off score of 7.5 produced the maximum sensitivity (.90) and specificity (.96) for the MSNQ (37).

Only one of the five studies that used the PRMQ reported the internal consistency, with Cronbach's alpha reported as 0.89, 0.84 and 0.80 (16). Again, validity was not reported. None of the three papers using the RBMT reported the reliability or validity of the measure, with only one paper suggesting that the test had been 'validated by five to ten years follow ups of patients with memory problems' (p. 161) (2). Of the four papers that used the Virtual Week, only one reported the split-half reliability (Cronbach's alpha ranged from 0.71 to 0.85 ) and none reported on the measure's validity (5). One of the two papers that used the CFQ reported the internal consistency reliability (Cronbach's alpha of 0.95) (7). Neither reported the validity. Only one of the four papers using the MFQ referenced the internal consistency reliability of the measure from other studies (Cronbach's alpha ranged from 0.84 to 0.94 ) and also stated that the measure 'has demonstrated concurrent validity and convergent validity with another 
commonly used metamemory measure' (p. 265, 14) (Gilewski et al., 1990; Hertzog, Hultsch, \& Dixon, 1989; Randolph et al., 2004; Zelinski, Gilewski, \& AnthonyBergstone, 1990). The study that used the CAMPROMPT reported inter-rater reliability $(r=.99)$ and 'adequate test-retest reliability over 7-10 days (Kendall's Tau-b $=0.64)$, and suggested the measure was 'ecologically valid' (3). Of the two papers that used the MIST, one paper referenced 'strong evidence of reliability and construct validity' (p. 890, 27) from other studies (Gupta et al., 2010; Woods et al., 2008), and one paper did not report the reliability or validity (16). Of the eight papers that used the PDQ, only two papers reported on reliability. One of the papers (36) reported internal consistency by referencing Cronbach's alpha ranges 0.77 - 0.97 from other studies (Fischer et al., 1999; Marrie et al., 2003) and also reported test-retest reliability $r=.564, p<.001$. The other paper reported internal consistency reliability from its own dataset with Cronbach's alpha ranging from 0.76 to 0.84 (44). Only three papers reported on the validity of the PDQ. The first paper reported the PDQ has 'good...validity in persons with MS' (p. 616, 36). The second paper did not find any correlations with objective cognitive tests and was 'uncertain' as to what the PDQ assesses (39). The third paper reported 'the validity of self-report measures of cognitive problems may best be addressed by examining whether these measures predict disruptions in daily living, not whether they predict neuropsychological test scores'. (p.103, 44). Papers using the MRS-C (13), and the Self-Evaluation of Everyday Memory and Learning Questionnaire (25) did not report on the reliability or validity of the measures.

Table 2 here 


\section{Discussion}

Everyday memory measures were used with a wide age range of people diagnosed with MS, with the mean number of years of education ranging from 11 to 15.7 years. Most of the participants were women and of White ethnicities, which is representative of the MS population. All MS sub-types were represented in the literature. Of the 12 everyday measures identified in the 44 papers, the majority were questionnaires, with only four being observer-assessed 'objective' tests that required the respondent to follow certain actions. These objective measures were the RBMT, CAMPROMPT, Virtual Week, and MIST.

Everyday memory measures were used for a variety of reasons: to assess how different everyday memory measures compare with each other, how everyday memory relates to other symptoms of MS (such as mood problems), and whether everyday memory can predict an outcome. Everyday memory measures were also used to screen participants for memory problems, and to classify and describe people's memory problems. Some trials of cognitive rehabilitation used everyday memory measures as a primary or secondary outcome to evaluate the impact of the intervention on everyday memory performance.

The variability of the use of these measures also suggests their versatility. Their versatility is also reflected in their administration formats, with the everyday memory questionnaires being administered face-to-face, over the phone, or by post. The questionnaires could also be self-administered. This is important for their use as outcome measures in intervention trials, because most of these trials are observerblinded and the chances of the outcome assessor becoming unblinded increases if they are in direct contact with participants. Indeed, many trials have imperfect blinding (Fergusson et al., 2004). This gets more difficult with participants with memory 
problems who even when told not to reveal their group allocation sometimes forget this instruction and inadvertently unblind the assessor (Lincoln, personal communication, 2017).

The majority of papers did not report or reference information related to reliability. Of the measures that did discuss reliability, one reported test-retest reliability (Kendall's Tau $=$ b-0.64) (Honan et al., 2015) and inter-rater reliability $(r=.99)$, and six discussed internal consistency (Cronbach's alphas ranging from 0.80 to 0.95 ). The validity of the measures was even less frequently presented. Where validity was discussed most authors presented a verbal description of the face validity, concurrent validity with independence and employment, and 'ecological validity'. Ecological validity refers to the extent to which cognitive tests relate to cognitive problems in daily living or functional limitations, emphasising how these tests predict function in real-life settings (Ginsberg, Kibby \& Long, 1996). Higginson et al. (2000) highlight the EMQ and RBMT as examples of ecologically valid tests of memory for use with people with MS; the EMQ, a rating scale assessing the frequency and of real-life memory problems, and the RBMT, a test which assesses analogues of everyday memory situations. Their study, which compared ecologically valid measures (memory questionnaires and tests) with standard neuropsychological tests (e.g., list learning and symbol-digit modalities test), found that the ecologically valid tests were better predictors of functional disability than both memory questionnaires and standard neuropsychological tests commonly used in assessing people with MS. The lack of correlations between some of these tests suggested that the ecologically valid tests measured something different than what was measured by the standard neuropsychological tests.

Everyday memory measures, therefore, have an important role to play in assessing memory functions in people with MS, predicting functional disability, 
establishing how everyday memory relates to other symptoms of MS, evaluating change over time, and examining the effectiveness of interventions.

One limitation of our review is that we did not assess the risk of bias or methodological quality of the included papers through a standardised checklist. Our aim was to clearly report all available evidence and synthesise findings, rather than presenting the 'weight' of the evidence. Thus, we cannot determine whether the included studies provide robust or generalisable findings.

\section{Conclusions}

This review presents researchers and clinicians with an overview of the various everyday memory measures that have been used in studies with people with MS. Everyday memory measures have been used for a variety of reasons with people with MS of different demographics and different MS subtypes. These measures are often questionnaires or objective tests with prescribed activities. The questionnaires are versatile, can be self-administered and can be used over the telephone or by post. Both the questionnaires and tests have been used as outcome measures in trials of cognitive rehabilitation. The measures have good reliability and appear to have good face, concurrent and ecological validity, but these need to be evaluated further in samples of people with MS.

\section{References}

Benedict, R. H. (2005). Effects of using same-versus alternate-form memory tests during short-interval repeated assessments in multiple sclerosis. Journal of the International Neuropsychological Society, 11(6), 727-36. doi.org/10.1017/S1355617705050782

Benedict, R. H., Cox, D., Thompson, L. L., Foley, F., Weinstock-Guttman, B., \& Munschauer, F. (2004). Reliable screening for neuropsychological impairment 
in multiple sclerosis. Multiple Sclerosis Journal, 10(6), 675-678. doi: 10.1191/1352458504ms1098oa

Benedict, R. H., Duquin, J. A., Jurgensen, S., Rudick, R. A., Feitcher, J., Munschauer, F. E., Panzara, M. A., \& Weinstock-Guttman, B. (2008). Repeated assessment of neuropsychological deficits in multiple sclerosis using the Symbol Digit Modalities Test and the MS Neuropsychological Screening Questionnaire. Multiple Sclerosis Journal, 14(7), 940-946. doi: 10.1177/1352458508090923.

Benedict, R. H., Fishman, I., McClellan, M. M., Bakshi, R., \& Weinstock-Guttman, B. (2003). Validity of the beck depression inventory-fast screen in multiple sclerosis. Multiple Sclerosis Journal, 9(4), 393-396.

Benedict, R. H., Munschauer, F., Linn, R., Miller, C., Murphy, E., \& Foley, F. W. (2003). Screening for multiple sclerosis cognitive impairment using a selfadministered 15-item questionnaire. Multiple Sclerosis Journal, 9(1), 95-101. doi: 10.1191/1352458503ms861oa

Benedict, R. H., \& Zivadinov, R. (2006). Predicting neuropsychological abnormalities in multiple sclerosis. Journal of the Neurological Sciences, 245(1), 67-72. https://doi.org/10.1016/j.jns.2005.05.020

Broadbent, D. E., Cooper, P. E., Fitzgerlad, P., \& Parkes, K.R. (1982). The cognitive failures questionnaire and its correlates. British Journal of Clinical Psychology, 21,1-16. DOI: 10.1111/j.2044-8260.1982.tb01421.x

Bruce, J. M., \& Arnett, P. A. (2004). Self-reported everyday memory and depression in patients with multiple sclerosis. Journal of Clinical and Experimental Neuropsychology, 26(2), 200-214. DOI: 10.1076/jcen.26.2.200.28081

Bruce, J. M., Bruce, A. S., Hancock, L., \& Lynch, S. (2010). Self-reported memory problems in multiple sclerosis: Influence of psychiatric status and normative dissociative experiences. Archives of Clinical Neuropsychology, 25(1), 39-48. doi:10.1093/arclin/acp092

Campbell, J., Rashid, W., Cercignani, M., \& Langdon, D. (2016). Cognitive impairment among patients with multiple sclerosis: associations with employment and quality of life. Postgraduate Medical Journal, 93(1097), 143-147. doi.org/10.1136/postgradmedj-2016-134071

Carone, D. A., Benedict, R. H., Munschauer, III. F. E., Fishman, I., \& WeinstockGuttman, B. (2005). Interpreting patient/informant discrepancies of reported 
cognitive symptoms in MS. Journal of the International Neuropsychological Society, 11(5), 574-83. DOI: https://doi.org/10.1017/S135561770505068X

Carr, S. E., dasNair, R., Schwartz, A. F., \& Lincoln, N. B. (2014). Group memory rehabilitation for people with multiple sclerosis: a feasibility randomized controlled trial. Clinical Rehabilitation, 28(6), 552-561. DOI: 10.12968/ijtr.2014.21.12.590

Chiaravalloti, N. D., DeLuca, J., Moore, N. B., \& Ricker, J. H. (2005). Treating learning impairments improves memory performance in multiple sclerosis: a randomized clinical trial. Multiple Sclerosis Journal, 11(1), 58-68. DOI: $10.1191 / 1352458505 \mathrm{~ms} 1118 \mathrm{oa}$

Chipchase, S. Y., \& Lincoln, N.B. (2001). Factors associated with carer strain in carers of people with multiple sclerosis. Disability and Rehabilitation, 23(17), 768776. doi.org/10.1080/09638280110062158

Christodoulou, C., Melville, P., Scherl, W. F., Morgan, T., MacAllister, W. S., Canfora, D. M., Berry, S. A., \& Krupp, L. B. (2005). Perceived cognitive dysfunction and observed neuropsychological performance: longitudinal relation in persons with multiple sclerosis. Journal of the International Neuropsychological Society, 11(5), 614-619. DOI: 10.10170S1355617705050733

Crawford, J., Smith, G., Maylor, E., Della Sala, S., \& Logie, R. (2003). The Prospective and Retrospective Memory Questionnaire (PRMQ): Normative data and latent structure in a large non-clinical sample. Memory, 11(3), 261-275. DOI: $10.1080 / 09658210244000027$

Cutajar, R., Ferriani, E., Scandellari, C., Sabattini, L., Trocino, C., Marchello, L. P., \& Stecchi, S. (2000). Cognitive function and quality of life in multiple sclerosis patients. Journal of Neurovirology, 6(2), S186. doi: 10.1186/1471-2377-11-17.

Dagenais, E., Rouleau, I., Demers, M., Jobin, C., Roger, E., Chamelian, L., \& Duquette, P. (2013). Value of the MoCA test as a screening instrument in multiple sclerosis. Canadian Journal of Neurological Sciences, 40(3), 410-415. DOI: $10.1017 / \mathrm{S} 0317167100014384$

Dagenais, E., Rouleau, I., Tremblay, A., Demers, M., Roger, É., Jobin, C., \& Duquette, P. (2016). Prospective memory in multiple sclerosis: The impact of cue distinctiveness and executive functioning. Brain and Cognition, 109, 66-74. https://doi.org/10.1016/j.bandc.2016.07.011 
dasNair, R., \& Lincoln, N.B. (2012). Evaluation of rehabilitation of memory in neurological disabilities (ReMiND): a randomized controlled trial. Clinical Rehabilitation, 26(10), 894-903. DOI: 10.1177/0269215511435424

dasNair, R., Martin, K.-J., \& Lincoln, N. (2016). Memory rehabilitation for people with multiple sclerosis. Cochrane Database of Systematic Reviews, 3, CD008754CD008754.

Demers, M., Rouleau, I., Scherzer, P., Ouellet, J., Jobin, C., \& Duquette, P. (2011). Impact of the cognitive status on the memory complaints in MS patients. Canadian Journal of Neurological Sciences, 38(5), 728-733. DOI: https://doi.org/10.1017/S031716710005410X

Erlanger, D. M., Kaushik, T., Caruso, L. S., Benedict, R. H., Foley, F. W., Wilken, J., Cadavid, D., \& Deluca, J. (2014). Reliability of a cognitive endpoint for use in a multiple sclerosis pharmaceutical trial. Journal of the Neurological Sciences, 340(1), 123-129. doi: 10.1016/j.jns.2014.03.009.

Feinstein, A. (2006). Mood disorders in multiple sclerosis and the effects on cognition. Journal of the Neurological Sciences, 245(1), 63-66. DOI: 10.1016/j.jns.2005.08.020

Fergusson, D., Glass, K. C., Waring, D., \& Shapiro, S. (2004). Turning a blind eye: the success of blinding reported in a random sample of randomised, placebo controlled trials. BMJ, 328(7437), 432. doi: https://doi.org/10.1136/bmj.328.74327.37952.631667.

Fischer, M., Kunkel, A., Bublak, P., Faiss, J. H., Hoffmann, F., Sailer, M., ... Köhler, W. (2014). How reliable is the classification of cognitive impairment across different criteria in early and late stages of multiple sclerosis? Journal of the Neurological Sciences, 343(1-2), 91-99. doi.org/10.1016/j.jns.2014.05.042

Fischer, J. S., LaRocca, N. G., Miller, D. M., Ritvo, P. G., Andrews, H., \& Paty, D. (1999). Recent developments in the assessment of quality of life in multiple sclerosis (MS). Multiple Sclerosis Journal, 5(4),251-259. Doi: $10.1177 / 135245859900500410$

Foley, J., Wilson, B., \& Shiel, A. (2004). Prospective memory in multiple sclerosis. Brain Impairment, 5(1), 99.

Gilchrist, A.C., \& Creed, F. H. (1994). Depression, cognitive impairment and social stress in multiple sclerosis. Journal of Psychosomatic Research, 38(3), 193-201. /doi.org/10.1016/0022-3999(94)90115-5 
Gilewski, M. J., Zelinski, E. M., \& Schaie, K.W. (1990). The memory functioning questionnaire for assessment of memory complaints in adulthood and old age. Psychology and Aging, 5(4), 482-490.

Ginsberg, J. P., Kibby, M. Y., \& Long, C. J. (1996). Ecological validity of neuropsychological data as indicated by interrelationships with vocational data. Archives of Clinical Neuropsychology, 11(5), 394-395.doi: https://doi.org/10.1093/arclin/11.5.394b

Gupta, S., Woods S. P., Weber, E., Dawson, M. S., Grant, I., \& HIV Neurobehavioral Research Center Group. (2010). Is prospective memory a dissociable cognitive function in HIV infection? Journal of Clinical and Experimental Neuropsychology, 32(8), 898-908. doi.org/10.1080/13803391003596470

Haupts, M., Calabrese, P., Babinsky, R., Markowitsch, H. J., \& Gehlen, W. (1994). Everyday memory impairment, neuroradiological findings and physical disability in multiple sclerosis. European Journal of Neurology,1(2), 159-163. DOI: 10.1111/j.1468-1331.1994.tb00065.x

Herrmann, D.J. (1984). Questionnaires about memory. In J.E. Harris \& P.E. Morris (eds.). Everyday Memory Actions and Absent-Mindedness. New York: Academic Press.

Hertzog, C., Hultsch, D. F., \& Dixon, R. A. (1989). Evidence for the convergent validity of two self-report metamemory questionnaires. Developmental Psychology, 25, 687-700. doi.org/10.1037/0012-1649.25.5.687

Honan, C. A., Brown, R. F., \& Batchelor, J. (2015). Perceived cognitive difficulties and cognitive test performance as predictors of employment outcomes in people with multiple sclerosis. Journal of the International Neuropsychological Society, 21(2), 156-168. DOI: https://doi.org/10.1017/S1355617715000053

Higginson, C. I, Arnett, P., \& Voss, W. D. (2000). The ecological validity of clinical tests of memory and attention in multiple sclerosis. Archives of Clinical Neuropsychology, 15, 185-204. doi.org/10.1016/S0887-6177(99)00004-9

Kardiasmenos, K. S., Clawson, D. M., Wilken, J. A., \& Wallin, M. T. (2008). Prospective memory and the efficacy of a memory strategy in multiple sclerosis. Neuropsychology, 22(6), 746-754. DOI: 10.1037/a0013211

Kinsinger, S. W., Lattie, E., \& Mohr, D. C. (2010). Relationship between depression, fatigue, subjective cognitive impairment, and objective neuropsychological functioning in patients with multiple sclerosis. Neuropsychology, 24(5), 573. 
Koss, E., Patterson, M. B., Ownby, R., Stuckey, J. C., \& Whitehouse, P. J. (1993).

Memory evaluation in Alzheimer's disease: caregivers' appraisals and objective testing. Archives of Neurology, 50(1), 92-97. DOI:

10.1001/archneur.1993.00540010086023

Krch, D., Sumowski, J. F., DeLuca, J., \& Chiaravalloti, N. (2011). Subjective memory in multiple sclerosis is associated with initial-trial learning performance. Journal of the Neuropsychological Society, 17(3), 557-561. DOI: https://doi.org/10.1017/S1355617711000336

Kujala, P., Portin, R., \& Ruutiainen, J. (1996). Memory deficits and early cognitive deterioration in MS. Acta Neurologica Scandinavica, 93(5), 329-335. DOI: 10.1111/j.1600-0404.1996.tb00005.x

Lester, K., Stepleman, L., \& Hughes, M. (2007). The association of illness severity, self-reported cognitive impairment, and perceived illness management with depression and anxiety in a multiple sclerosis clinic population. Journal of Behavioral Medicine, 30(2), 177-186. DOI: 10.1007/s10865-007-9095-6

Lincoln, N. B., Dent, A., Harding, J., Weyman, N., Nicholl, C., Blumhardt, L. D., \& Playford, E. D. (2002). Evaluation of cognitive assessment and cognitive intervention for people with multiple sclerosis. Journal of Neurology, Neurosurgery \& Psychiatry, 72(1), 93-98. http://dx.doi.org/10.1136/jnnp.72.1.93

Lincoln, N. B., \& Tinson, D. J. (1989). The relation between subjective and objective memory impairment after stroke. British Journal of Clinical Psychology, 28(1), 61-65. DOI: 10.1111/j.2044-8260.1989.tb00812.x

Lovera, J., Bagert, B., Smoot, K. H, \& Wild, K. (2006). Correlations of perceived deficits questionnaire of multiple sclerosis quality of life inventory with beck depression inventory and neuropsychological tests. Journal of Rehabilitation Research and Development, 43(1), 73-82. DOI: 10.1682/JRRD.2004.09.0118

Mackenzie, I. S., Morant, S. V., Bloomfield, G. A., MacDonald, T. M., \& O’Riordan, J. (2014). Incidence and prevalence of multiple sclerosis in the UK 1990-2010: a descriptive study in the General Practice Research Database. Journal of Neurology, Neurosurgery \& Psychiatry, 85(1), 76 -84. doi.org/10.1136/jnnp2013-305450

Mäntynen, A., Rosti-Otajärvi, E., Koivisto, K., Lilja, A., Huhtala, H., \& Hämäläinen, P. (2014). Neuropsychological rehabilitation does not improve cognitive 
performance but reduces perceived cognitive deficits in patients with multiple sclerosis: a randomised, controlled, multi-centre trial. Multiple Sclerosis Journal, 20(1), 99-107. doi: 10.1177/1352458513494487.

Marrie, R. A., Miller, D. M., Chelune, G. J., \& Cohen, J. A. (2003). Validity and reliability of the MSQLI in cognitively impaired patients with multiple sclerosis. Multiple Sclerosis Journal, 9(6), 621-626.doi: 10.1191/1352458503ms971oa McGlone, J., Gupta, S., Humphrey, D., Oppenheimer, S., Mirsen, T., \& Evans, D. R. (1990). Screening for early dementia using memory complaints from patients and relatives. Archives of Neurology, 47(11), 1189-1193. doi:10.1001/archneur.1990.00530110043015

McIntosh-Michaelis S. A., Roberts, M. H., Wilkinson, S. M., Diamond, I. D., McLellan, D. L., Martin, J. P., \& Spackman, A. J. (1991). The prevalence of cognitive impairment in a community survey of multiple sclerosis. British Journal of Clinical Psychology, 30(4), 333-348. DOI: 10.1111/j.2044-8260.1991.tb00954.x

Middleton, L. S., Denney, D. R., Lynch, S. G., \& Parmenter, B. (2006). The relationship between perceived and objective cognitive functioning in multiple sclerosis. Archives of Clinical Neuropsychology, 21(5), 487-494. doi.org/10.1016/j.acn.2006.06.008

Miller, A. K., Basso, M. R., Candilis, P. J., Combs, D. R., \& Woods, S. P. (2014) Pain is associated with prospective memory dysfunction in multiple sclerosis. Journal of Clinical and Experimental Neuropsychology, 36(8), 887-896. doi.org/10.1080/13803395.2014.953040

Moher, D., Liberati, A., Tetzlaff, J., Altman, D.G., \& The PRISMA Group. (2009). Preferred reporting items for systematic reviews and meta-analyses: the PRISMA statement. PLoS Medicine, 6(7), e1000097. doi.org/10.1371/journal.pmed.1000097

Moradi, A., Afsardeir, B., Parhoon, H., \& Sanaei, H. (2016). Cognitive performance of patients with Multiple Sclerosis (MS) in autobiographical, working and prospective memory in comparison with normal people. International Journal of Behavioral Sciences, 10(2),49-54.

O’Brien, A., Gaudino-Goering, E., Shawaryn, M., Komaroff, E., Moore, N. B., \& DeLuca, J. (2007). Relationship of the Multiple Sclerosis Neuropsychological Questionnaire (MSNQ) to functional, emotional, and neuropsychological 
outcomes. Archives of Clinical Neuropsychology, 22(8), 933-948.

doi.org/10.1016/j.acn.2007.07.002

Pérez-Martín, M. Y., González-Platas, M., Eguía-del Río, P., Croissier-Elías, C., \& Sosa, A. J.(2017). Efficacy of a short cognitive training program in patients with multiple sclerosis. Neuropsychiatric Disease and Treatment, 13, 245-252. doi: $10.2147 /$ ndt.s124448

Peyser, J. M., Rao, S. M., LaRocca, N. G., \& Kaplan, E. (1990). Guidelines for neuropsychological research in multiple sclerosis. Archives of Neurology, 47(1), 94-97. doi:10.1001/archneur.1990.00530010120030

Phillips, L.H., Saldias, A., McCarrey, A., Henry, J. D., Scott, C., Summers, F., \& Whyte, M. (2009). Attentional lapses, emotional regulation and quality of life in multiple sclerosis. British Journal of Clinical Psychology, 48(1), 101-106. DOI: $10.1348 / 014466508 \times 379566$

Randolph, J. J., Arnett, P. A., \& Freske, P. (2004). Metamemory in multiple sclerosis: Exploring affective and executive contributors. Archives of Clinical Neuropsychology, 19(2), 259-279. doi.org/10.1016/S0887-6177(03)00026-X

Rao, S. M., Hammeke, T. A., McQuillen, M. P., Khatri, B. O., \& Lloyd, D. (1984). Memory disturbance in chronic progressive multiple sclerosis. Archives of Neurology, 41(6), 625-631.

Rao, S. M., Leo, G. J., Bernardin, L., \& Unverzagt, F. (1991). Cognitive dysfunction in multiple sclerosis. I. Frequency, patterns, and prediction. Neurology, 41(5), 685 -691. DOI: 10.1212/WNL.41.5.685

Raskin, S. A. (2009). Memory for intentions screening test: Psychometric properties and clinical evidence. Brain Impairment, 10(1), 23-33. DOI: 10.1375/brim.10.1.23

Raskin, S., Buckheit, C., \& Sherrod, C. (2010). MIST Memory for Intentions Test professional manual. Lutz: Psychological Assessment Resources.

Rendell, P.G., \& Craik, F. I. M. (2000). Virtual week and actual week: Age-related differences in prospective memory. Applied Cognitive Psychology, 12, S43-S62. DOI: $10.1002 /$ acp. 770

Rendell, P. G., Henry, J. D., Phillips, L. H., de la Piedad Garcia, X., Booth, P., Phillips, P., \& Kliegel, M. (2012). Prospective memory, emotional valence, and multiple sclerosis. Journal of Clinical and Experimental Neuropsychology; 34(7), 738749. DOI: $10.1080 / 13803395.2012 .670388$ 
Rendell, P. G., Jensen, F., \& Henry, J. D. (2007). Prospective memory in multiple sclerosis. Journal of the International Neuropsychological Society, 13(3), 410416. DOI: https://doi.org/10.1017/S1355617707070579

Rendell, P. G., Karpivensky, N., Wallis, A., et al. (2002). Bipolar disorder and prospective memory. In: Inaugural Australian Bipolar Disorder Conference: The ups and downs of a neglected disorder, Melbourne, Australia.

Richardson, J. T. (1996). Memory impairment in multiple sclerosis: reports of patients and relatives. British Journal of Clinical Psychology, 35(2), 205-219. DOI: 10.1111/j.2044-8260.1996.tb01177.x

Robertson, I. H., Manly, T., Andrade, J., Baddeley, B. T., \& Yiend, J. (1997). 'Oops!': performance correlates of everyday attentional failures in traumatic brain injured and normal subjects, Neuropsychologia, 35, 747-758. doi.org/10.1016/S00283932(97)00015-8

Rosti-Otajärvi, E., Mäntynen, A., Koivisto, K., Huhtala, H., \& Hämäläinen, P. (2013). Neuropsychological rehabilitation has beneficial effects on perceived cognitive deficits in multiple sclerosis during nine-month follow-up. Journal of the Neurological Sciences, 334(1), 154-160.

Royle, J., \& Lincoln, N.B. (2008). The Everyday Memory Questionnaire-revised: Development of a 13-item scale. Disability and Rehabilitation, 30(2), 114-121. doi.org/10.1080/09638280701223876

Samartzis, L., Gavala, E., Zoukos, Y., Aspiotis, A., \& Thomaides, T. (2014). Perceived cognitive decline in multiple sclerosis impacts quality of life independently of depression. Rehabilitation Research and Practice, 1-6. doi.org/10.1155/2014/128751

Shevil, E., \& Finlayson, M. (2010). Pilot study of a cognitive intervention program for persons with multiple sclerosis. Health Education Research, 25(1), 41-53. doi.org/10.1093/her/cyp037

Smith, A. (1982). Symbol Digit Modalities Test: manual. Los Angeles: Western Psychological Services.

Smith, G., Della-Sala, S., Logie, R., \& Maylor, E. A. (2000). Prospective and retrospective memory in normal ageing and dementia: A questionnaire study. Memory, 8, 311-321. DOI: 10.3758/BF03195773

Sonder, J. M., Mokkink, L. B., van der Linden, F. A., Polman, C. H., \& Uitdehaag, B. M. (2012). Validation and interpretation of the Dutch version of the Multiple 
Sclerosis Neuropsychological Screening Questionnaire. Journal of the Neurological Sciences, 320(1), 91-96. doi: 10.1016/j.jns.2012.06.024

Strober, L. B., Binder, A., Nikelshpur, O. M., Chiaravalloti, N., \& DeLuca, J. (2016). The Perceived Deficits Questionnaire: Perception, Deficit, or Distress?. International Journal of MS Care, 18(4), 183-190. doi: 10.7224/15372073.2015-028.

Stuifbergen, A. K., Becker, H., Perez, F., Morison, J., Kullberg, V., \& Todd, A. (2012). A randomized controlled trial of a cognitive rehabilitation intervention for persons with multiple sclerosis. Clinical Rehabilitation, 26(10), 882-893. doi: $10.1177 / 0269215511434997$

Sullivan, J. I. L, Edgley, K., \& DeHoux, E. (1990). A survey of multiple sclerosis: Part 1. Perceived cognitive problems and compensatory strategy use. Canadian Journal of Rehabilitation, 4, 99-105.

Sunderland, A., Harris, J.E., \& Baddeley, A.D. (1983). Do laboratory tests predict everyday memory? A neuropsychological study. Journal of Verbal Learning and Verbal Behavior, 22, 341-357. DOI: 10.1016/S0022-5371(83)90229-3

Tate, R. L. (2010). A compendium of tests, scales, and questionnaires: The practitioner's guide to measuring outcomes after acquired brain impairment. Hove: Psychology Press.

Thelen, J. M., Lynch, S. G., Bruce, A. S., Hancock, L. M., \& Bruce, J. M. (2014). Polypharmacy in multiple sclerosis: relationship with fatigue, perceived cognition, and objective cognitive performance. Journal of Psychosomatic Research, 76(5), 400-404. doi: 10.1016/j.jpsychores.2014.02.013.

Vanotti, S., Benedict, R. H, Acion, L., \& Caceres, F. (2009). Validation of the multiple sclerosis neuropsychological screening questionnaire in Argentina. Multiple Sclerosis Journal, 15(2), 244-50. Doi: 10.1177/1352458508097924

Walker, L. A., Osman, L., Berard, J. A., Rees, L. M., Freedman, M. S., MacLean, H., \& Cousineau D. (2016). Brief International Cognitive Assessment for Multiple Sclerosis (BICAMS): Canadian contribution to the international validation project. Journal of the Neurological Sciences 362,147-52. doi: 10.1016/j.jns.2016.01.040.

West, R., McNerney, M. W., \& Krauss, I. (2007). Impaired strategic monitoring as the locus of a focal prospective memory deficit. Neurocase, 13(2), 115-126. doi.org/10.1080/13554790701399247 
Wilson B. A. (1991). Long-term prognosis of patients with severe memory disorders. Neuropsychological Rehabilitation, 1(2): 117-134. doi.org/10.1080/09602019108401386

Wilson, B. A., Cockburn, J., \& Baddeley, A. D. (1985). The Rivermead Behavioural Memory Test. London: Pearson Assessment.

Wilson, B. A., Clare, L., Baddeley, A. D., Cockburn, J., Watson, P., \& Tate, R. (1999). The Rivermead Behavioural Memory Test - Extended Version. Bury St. Edmunds: Thames Valley Test Company.

Wilson, B. A., Emslie, H., Foley, J., Shiel, A., Watson, P., Hawkins, K., Groot, Y. \& Evans, J.J. (2005). The Cambridge Prospective Memory Test (CAMPROMPT) London: Harcourt Assessment.

Woods, S. P., Ludicello, J. E., Moran, L. M., Carey, C. L., Dawson, M. S., \& Grant, I. (2008). HIV-associated prospective memory impairment increases risk of dependence in everyday functioning. Neuropsychology, 22(1),110-117. doi: 10.1037/0894-4105.22.1.110

Woods, S. P., Moran, L. M., Dawson, M. S., Carey, C.L., Grant, I., \& HIV Neurobehavioral Research Center Group. (2008). Psychometric characteristics of the memory for intentions screening test. Clinical Neuropsycholist, 22(5), 864-878. doi:10.1080/13854040701595999.

World Health Organization. (2007). International Classification of Functioning, Disability, and Health: Children \& Youth Version: ICF-CY. Geneva: World Health Organization.

Zelinski, E., Gilewski, M., \& Anthony-Bergstone, C. (1990). The Memory Functioning Questionnaire: Concurrent validity with memory performance and self-reported memory failures. Psychology and Aging, 51, 388-399. DOI: 10.1037//08827974.5.3.388 
Table 1. Scoring, administration, reliability and validity of EM measures.

Table 2. Reliability and validity of EM measures in MS samples.

Figure 1. PRISMA flowchart for searches. 
Table 1. Scoring, administration, reliability and validity of EM measures

\begin{tabular}{|c|c|c|c|c|c|}
\hline $\begin{array}{l}\text { Questionnaires/ } \\
\text { Tests }\end{array}$ & $\begin{array}{l}\text { Number of } \\
\text { items/subtests }\end{array}$ & Scaling and scoring & $\begin{array}{l}\text { Administration } \\
\text { time }\end{array}$ & Administration modality & Reliability and validity \\
\hline CFQ & 25 items & $\begin{array}{l}\text { Likert scale scored } 0 \\
\text { (never) to } 4 \text { (very } \\
\text { often) }\end{array}$ & Not reported & $\begin{array}{l}\text { Two papers reported } \\
\text { using postal } \\
\text { administration (7) and } \\
\text { face-to-face } \\
\text { administration (19) }\end{array}$ & $\begin{array}{l}\text { The factor structure of the CFQ varied } \\
\text { between occupational groups (Broadbent } \\
\text { et al., 1982). }\end{array}$ \\
\hline EMQ & $\begin{array}{l}35 \text { items ( } 28 \text { in } \\
\text { revised version) }\end{array}$ & $\begin{array}{l}\text { Likert scale scored } 0 \\
\text { (never) to } 4 \text { (more } \\
\text { than once a day). } \\
\text { Total score is sum of } \\
\text { all items. }\end{array}$ & Not reported & $\begin{array}{l}\text { Five papers reported } \\
\text { using postal and inferred } \\
\text { postal administration }(1, \\
4,10,11) \text { and inferred } \\
\text { face-to face }(9)\end{array}$ & \\
\hline MFQ & $\begin{array}{l}64 \text { items, } 7 \\
\text { sections }\end{array}$ & $\begin{array}{l}7 \text { point Likert scale } \\
\text { (never to always) }\end{array}$ & Not reported & $\begin{array}{l}\text { Three papers reported } \\
\text { face-to-face and inferred } \\
\text { face-to-face } \\
\text { administration }(14,15 \text {, } \\
43)\end{array}$ & \\
\hline MRS-C & 31 items & $\begin{array}{l}\text { Likert scale scored } 1 \\
\text { (much worse than the } \\
\text { average person) to } 5 \\
\text { (much better than the } \\
\text { average person) }\end{array}$ & Not reported & Not reported & \\
\hline
\end{tabular}




\begin{tabular}{|c|c|c|c|c|c|}
\hline $\begin{array}{l}\text { Questionnaires/ } \\
\text { Tests }\end{array}$ & $\begin{array}{l}\text { Number of } \\
\text { items/subtests }\end{array}$ & Scaling and scoring & $\begin{array}{l}\text { Administration } \\
\text { time }\end{array}$ & Administration modality & Reliability and validity \\
\hline MSNQ & 15 items & $\begin{array}{l}\text { Likert scale scored } 0 \\
\text { (never) to } 4 \text { (very } \\
\text { often) }\end{array}$ & Not reported & $\begin{array}{l}\text { Thirteen papers reported } \\
\text { using face-to-face or } \\
\text { inferred face-to-face } \\
\text { administration }(15,23, \\
26,28,31,32,34,35,37, \\
40,42) \text {, self- } \\
\text { administration and postal } \\
\text { administration (30) and } \\
\text { telephone administration } \\
\text { (33) }\end{array}$ & $\begin{array}{l}\text { "Cronbach's alpha coefficients were } 0.93 \\
\text { and } 0.94 \text { for the patient- and informant- } \\
\text { report forms, respectively, and both forms } \\
\text { of the test were strongly correlated with a } \\
\text { more general cognitive complaints } \\
\text { questionnaire. The patient MSNQ form } \\
\text { correlated significantly with measures of } \\
\text { depression but not with objective tests of } \\
\text { cognitive function. In contrast, the } \\
\text { informant form was correlated with } \\
\text { patient cognitive performance but not } \\
\text { depression. A cut-off score of } 27 \text { on the } \\
\text { informant form of the MSNQ optimally } \\
\text { separated patients based on a } \\
\text { neuropsychological summary score } \\
\text { encompassing measures of processing } \\
\text { speed and memory. There were two false- } \\
\text { negatives and one false-positive, giving } \\
\text { the test a sensitivity of } 0.83 \text { and a } \\
\text { specificity of } 0.97 \text { " (Benedict et al., 2003) }\end{array}$ \\
\hline PDQ & 20 items & $\begin{array}{l}\text { Likert scale scored } 1 \\
\text { (never) to } 5 \text { (almost } \\
\text { always) }\end{array}$ & Not reported & $\begin{array}{l}\text { Six papers reported using } \\
\text { telephone administration } \\
(17), \text { inferred face-to-face } \\
(31,32) \text {, self- } \\
\text { administration (38), postal } \\
\text { administration (39) and }\end{array}$ & $\begin{array}{l}\text { Analyses revealed that the } 4 \text { subscales } \\
\text { were internally consistent: } \\
\text { attention/concentration (alpha }=0.78 \text { ), } \\
\text { planning/organization (alpha }=0.84) \text {, } \\
\text { retrospective memory (alpha }=0.83 \text { ), } \\
\text { prospective memory (alpha }=0.76 \text { ). } \\
\text { Principal components analysis with }\end{array}$ \\
\hline
\end{tabular}




\begin{tabular}{|c|c|c|c|c|c|}
\hline $\begin{array}{l}\text { Questionnaires/ } \\
\text { Tests }\end{array}$ & $\begin{array}{l}\text { Number of } \\
\text { items/subtests }\end{array}$ & Scaling and scoring & $\begin{array}{l}\text { Administration } \\
\text { time }\end{array}$ & Administration modality & Reliability and validity \\
\hline & & & & $\begin{array}{l}\text { posted in a newsletter } \\
(44)\end{array}$ & $\begin{array}{l}\text { oblique rotation yielded a } 4 \text {-factor } \\
\text { solution that paralleled the subscale } \\
\text { structure. Inter-factor correlations } \\
\text { averaged } 0.45 \text { (p.102) (44). }\end{array}$ \\
\hline PRMQ & 16 items & $\begin{array}{l}\text { Likert scale scored } 1 \\
\text { (never) to } 5 \text { (very } \\
\text { often) }\end{array}$ & Not reported & $\begin{array}{l}\text { Four papers reported } \\
\text { using face-to-face and } \\
\text { inferred face-to-face } \\
\text { administration }(18,22 \text {, } \\
16,20)\end{array}$ & $\begin{array}{l}\text { Has self and proxy rating versions, } \\
\text { normative data from } 555 \text { healthy controls } \\
\text { aged } 17-94 \text { years (Crawford et al., 2003). } \\
\text { "We examined the split half reliability of } \\
\text { the questionnaire, comparing the two } \\
\text { questions within each category from the } \\
\text { elderly and young control participants } \\
\text { only ( } n=406 \text { ). Using the Spearman- } \\
\text { Brown formula, the split half reliability } \\
\text { was } r \mathrm{SB}=0.84 . " \text { (p. } 315 \text { ) (Smith et al. } \\
2000)\end{array}$ \\
\hline $\begin{array}{l}\text { Self-evaluation of } \\
\text { memory and } \\
\text { learning }\end{array}$ & $\begin{array}{l}\text { Data } \\
\text { Unavailable }\end{array}$ & $\begin{array}{l}\text { Likert scale scored } 1 \\
\text { (never) to } 5 \text { (often) }\end{array}$ & Not reported & Self-administered & $\begin{array}{l}\text { From personal communications with } \\
\text { author ( } 24 \text { th August 2016), no } \\
\text { psychometric properties were available. }\end{array}$ \\
\hline CAMPROMPT & 6 tasks & Data unavailable & $25 \mathrm{mins}$ & $\begin{array}{l}\text { Needs trained } \\
\text { administrator; Face-to- } \\
\text { face }\end{array}$ & \\
\hline MIST & 8 tasks & $\begin{array}{l}6 \text { subscales ranging } \\
0-8, \text { summed into } \\
\text { summary score } \\
\text { ranging } 0-48\end{array}$ & $30 \mathrm{mins}$ & $\begin{array}{l}\text { Needs trained } \\
\text { administrator; face-to- } \\
\text { face }\end{array}$ & \\
\hline
\end{tabular}




\begin{tabular}{|c|c|c|c|c|}
\hline $\begin{array}{l}\text { Questionnaires/ } \\
\text { Tests }\end{array}$ & $\begin{array}{l}\text { Number of } \\
\text { items/subtests }\end{array}$ & Scaling and scoring & $\begin{array}{l}\text { Administration } \\
\text { time }\end{array}$ & Administration modality $\quad$ Reliability and validity \\
\hline RBMT & 14 tasks & $\begin{array}{l}\text { Gives standardised } \\
\text { scores and percentile } \\
\text { rank with cut-off data } \\
\text { for impairment level }\end{array}$ & $30 \mathrm{mins}$ & $\begin{array}{l}\text { Needs trained } \\
\text { administrator; Face-to- } \\
\text { face }\end{array}$ \\
\hline Virtual Week & $\begin{array}{l}3 \text { different types } \\
\text { of tasks }\end{array}$ & $\begin{array}{l}\text { Scored on tasks } \\
\text { correct, incorrect, } \\
\text { late or missed. }\end{array}$ & $75-120 \mathrm{mins}$ & $\begin{array}{l}\text { Needs trained } \\
\text { administrator; Board } \\
\text { game or computerised, } \\
\text { individual or group }\end{array}$ \\
\hline
\end{tabular}

Note. Abbreviations: CAMPROMPT: Cambridge Prospective Memory Test; CFQ: Cognitive Failures Questionnaire; EM: Everyday memory; EMQ:

Everyday Memory Questionnaire; MFQ: Memory Functioning Questionnaire; MIST: Memory for Intentions Screening Test; MRS: Memory Rating Scale;

MS: Multiple Sclerosis; MSNQ: MS Neuropsychological Questionnaire (MSNQ-P: patient self-report version; MSNQ-I: Informant version); PDQ: Perceived

Deficits Questionnaire; PRMQ: Prospective and Retrospective Memory Questionnaire; RBMT: Rivermead Behavioural Memory Test. 
Table 2. Reliability and validity of EM measures in MS samples

\begin{tabular}{|c|c|c|c|}
\hline $\begin{array}{l}\text { EM Measure } \\
\text { (no. of papers } \\
\text { used in) }\end{array}$ & Reliability in MS samples & Validity in MS samples & Other Comments \\
\hline \multirow{4}{*}{ EMQ (6) } & Not Reported & $\begin{array}{l}\text { The EMQ 'has good face validity, } \\
\text { assesses real-life situations...' (p.897) } \\
\text { (das Nair et al. 2012) }\end{array}$ & $\begin{array}{l}\text { '....and is used in clinical practice' } \\
\text { (p.897) (das Nair et al. 2012) }\end{array}$ \\
\hline & $\begin{array}{l}\text { 'Cronbach's alpha for the scale was } \\
\text { high (0.91)' (p.117) (Royle et al. } \\
2008) \text { (controls only) } \\
\text { 'Cronbach's alpha for the shortened } \\
\text { scale was high (0.89) and all items } \\
\text { showed corrected item-total } \\
\text { correlations of at least 0.3, } \\
\text { indicating strong internal reliability' } \\
\text { (p.117-8) (Royle et al. 2008) (both } \\
\text { groups) }\end{array}$ & $\begin{array}{l}\text { '...good face validity' (p. 114) (Royle et } \\
\text { al. 2008) } \\
\text { 'Further evidence of the validity of the } \\
\text { revised scaled was confirmed by the } \\
\text { strong relationships between the original } \\
\text { and revised versions, suggesting that the } \\
\text { revised 13-item questionnaire could } \\
\text { provide a valid and reliable tool for } \\
\text { clinical use...' (p.119) (Royle et al. } \\
\text { 2008) }\end{array}$ & $\begin{array}{l}\text { The EMQ 'was initially developed for } \\
\text { use with survivors of head injury } \\
\text {...further refined... with both non- } \\
\text { clinical and clinical samples'. (p. 115) } \\
\text { (Royle et al.2008) } \\
\text { 'The original questionnaire consisted of } \\
35 \text { items, which has since been altered } \\
\text { to } 28 \text {-item questionnaire to increase the } \\
\text { measure's validity and facilitate self- } \\
\text { administration'. (p. 115) (Royle et al. } \\
\text { 2008) }\end{array}$ \\
\hline & Not Reported & Not Reported & $\begin{array}{l}\text { 'The outcome measures used (including } \\
\text { EMQ) may not be appropriate to detect } \\
\text { the benefits of providing an } \\
\text { intervention' (p.97)(Lincoln et al. 2002) }\end{array}$ \\
\hline & Not Reported & Not Reported & $\begin{array}{l}\text { 'Only a few items from the Everyday } \\
\text { Memory Questionnaire completed by } \\
\text { the person with MS were associated }\end{array}$ \\
\hline
\end{tabular}




\begin{tabular}{|c|c|c|c|}
\hline $\begin{array}{l}\text { EM Measure } \\
\text { (no. of papers } \\
\text { used in) }\end{array}$ & Reliability in MS samples & Validity in MS samples & Other Comments \\
\hline & & & $\begin{array}{l}\text { with carer strain, and there was no } \\
\text { apparent difference between those items } \\
\text { that were related... and those that were } \\
\text { not...' (p. 772) (Chipchase et al. 2001) }\end{array}$ \\
\hline & Not Reported & Not Reported & \\
\hline & Not Reported & Not Reported & $\begin{array}{l}\text { The EMQ 'was used as there was no } \\
\text { appropriate alternative available with } \\
\text { good psychometric properties' (p.559) } \\
\text { (Carr et al. 2014) }\end{array}$ \\
\hline \multirow{3}{*}{ MSNQ (14) } & Not Reported & Not Reported & \\
\hline & $\begin{array}{l}\text { The MSNQ 'appears reliable to } \\
\text { detect cognitive impairment (p.410) } \\
\text { (Stuifbergen et al. 2012) }\end{array}$ & Not Reported & $\begin{array}{l}\text { 'There was a strong correlation between } \\
\text { the results obtained on the } \\
\text { neuropsychological tests at least for } \\
\text { memory functioning, and the score on } \\
\text { the MSNQ-informant.' (p.413) } \\
\text { (Stuifbergen et al. 2012) }\end{array}$ \\
\hline & $\begin{array}{l}\text { 'The Cronbach's alpha for internal } \\
\text { consistency reliability ranged from } \\
0.94 \text { to } 0.95 \text { ' (p.886) (Cutajar et al. } \\
2000)\end{array}$ & Not Reported & $\begin{array}{l}\text { MSNQ 'scores were significantly } \\
\text { correlated with scores on a battery of } \\
\text { neuropsychological tests and measures } \\
\text { of whole-brain lesion burden and } \\
\text { atrophy in prior research' (p.886) } \\
\text { (Cutajar et al. 2000) (Benedict et al. } \\
\text { 2004; Benedict \& Zinadinov, 2006) }\end{array}$ \\
\hline
\end{tabular}




\begin{tabular}{|c|c|c|c|}
\hline $\begin{array}{l}\text { EM Measure } \\
\text { (no. of papers }\end{array}$ & Reliability in MS samples & Validity in MS samples & Other Comments \\
\hline & Not Reported & Not Reported & \\
\hline & Not Reported & Not Reported & \\
\hline & $\begin{array}{l}\text { Cronbach's alpha for MSNQ-P } 0.93 \\
\text { and MSNQ-I } 0.94 \text { showed good } \\
\text { internal consistency. } \\
\text { Interrater reliability between } \\
\text { MSNQ-P and MSNQ-I was } \\
\text { moderate, with Intraclass } \\
\text { Correlation coefficient of } 0.59(95 \% \\
\text { CI: } 0.46-0.69) \text {. } \\
\text { Weighted kappa values for item } \\
\text { scores were low to moderate }(0.25- \\
0.50)\end{array}$ & $\begin{array}{l}\text { Construct validity was confirmed } \\
\text { through six hypotheses: } \\
\text { 1) Correlation between MSNQ-P } \\
\text { and BRBN small positive, } 0.26 \\
\text { 2) Correlation between MSNQ-I } \\
\text { and BRBN moderate and } \\
\text { positive, } 0.39 \\
\text { 3) Correlation between MSNQ-P } \\
\text { and anxiety and depression } \\
\text { scales (HADS) moderate and } \\
\text { positive, } 0.49 \text { and } 0.47 \\
\text { respectively } \\
\text { 4) Correlation between MSNQ-I } \\
\text { and anxiety and depression small } \\
\text { positive, } 0.36 \text { and } 0.33 \\
\text { 5) Correlations between MSNQ-P } \\
\text { and BRBN small positive, } 0.26 \\
\text { and correlation between MSNQ- } \\
\text { I and BRBN is higher, } 0.39 \\
\text { 6) Correlation between MSNQ-P } \\
\text { and anxiety and depression, } 0.47\end{array}$ & $\begin{array}{l}\text { 'Internal consistency was good for both } \\
\text { scales. Assessment of construct validity } \\
\text { showed that all hypotheses based on } \\
\text { previous studies were confirmed } \\
\text { (Benedict et al. 2003; Vanotti et al. } \\
\text { 2009)'. } \\
\text { 'The interrater reliability of the total } \\
\text { score and the item scores between the } \\
\text { patient and informant versions was } \\
\text { moderate'. } \\
\text { 'Interrater agreement was poor'. } \\
\text { 'The main outcome is that the MSNQ-I } \\
\text { is more promising to screen for } \\
\text { cognitive impairment in MS patients. } \\
\text { The patient version has no added value, } \\
\text { so when screening for cognitive } \\
\text { impairment in MS the MSNQ version is } \\
\text { preferred'. (p. 95) (Sonder et al. 2012) }\end{array}$ \\
\hline
\end{tabular}




\begin{tabular}{|c|c|c|c|}
\hline $\begin{array}{l}\text { EM Measure } \\
\text { (no. of papers } \\
\text { used in) }\end{array}$ & Reliability in MS samples & Validity in MS samples & Other Comments \\
\hline \multicolumn{4}{|c|}{$\begin{array}{l}\text { and } 0.49 \text { respectively. } \\
\text { Correlation between MSNQ-I } \\
\text { and anxiety and depression is } \\
\text { lower, } 0.33 \text { and } 0.36 \\
\text { respectively. (p. 94) (Sonder et } \\
\text { al. 2012) }\end{array}$} \\
\hline & Not Reported & Not reported & \\
\hline & Not Reported & Not Reported & \\
\hline & Not Reported & Not Reported & \\
\hline & $\begin{array}{l}\text { 'Test-retest correlations ranged } \\
\text { from.0.86 [test } 2 \text { to test 3] to } 0.90 \\
\text { [test } 3 \text { to test } 4 \text { for MSNQ.' (p. } 943 \text { ) } \\
\text { (Benedict et al. 2008) } \\
\text { 'Our results clearly show that } \\
\text { SDMT and MSNQ are reliable when } \\
\text { administered by nursing staff at } \\
\text { monthly intervals.' (p. 944) } \\
\text { (Benedict et al. 2008). } \\
\text { 'Test-retest coefficients were } \\
\text { acceptable to strong for both tests } \\
\text { and showed very little variation over } \\
\text { the course of the study.' (p. 944) } \\
\text { (Benedict et al. 2008) }\end{array}$ & $\begin{array}{l}\mathrm{R}^{2} \text { final model: } \\
\text { Month 2=0.40 (BDIFS and SDMT), } \\
\text { Month 3=0.37(BDIFS), Month 4=0.38 } \\
\text { (BDIFS), Month 5=0.28 (BDIFS and } \\
\text { SDMT), Month 6=0.38 (BDIFS and } \\
\text { SDMT) } \\
\text { 'The final } \mathrm{R}^{2} \text { values ranged from } 0.28 \text { to } \\
0.40 \text {, suggesting that SDMT and BDIFS } \\
\text { combined account for roughly } 1 / 3 \text { of the } \\
\text { variance in MSNQ.' } \\
\text { 'The question of validity was also } \\
\text { examined in the regression models } \\
\text { where we attempted to determine the }\end{array}$ & $\begin{array}{l}\text { 'The current findings parallel previous } \\
\text { showing good test-retest reliability with } \\
\text { these measures using a weekly } \\
\text { assessment schedule (Benedict et al. } \\
\text { 2004; Benedict, Cox, Thompson et al. } \\
\text { 2004)(p.944) (Benedict et al. 2008) } \\
\text { (post hoc rationale) 'The high reliability } \\
\text { for the SDMT and MSNQ when used on } \\
\text { a monthly basis means that these tests } \\
\text { can be used to identify patients at high } \\
\text { risk for neuropsychological compromise } \\
\text { with minimal error, in the clinic setting.' } \\
\text { (p. 944) (Benedict et al. 2008) }\end{array}$ \\
\hline
\end{tabular}




\begin{tabular}{|c|c|c|c|}
\hline $\begin{array}{l}\text { EM Measure } \\
\text { (no. of papers } \\
\text { used in) }\end{array}$ & Reliability in MS samples & Validity in MS samples & Other Comments \\
\hline & & $\begin{array}{l}\text { most significant correlate of the } \\
\text { MSNQ.....it was understood that } \\
\text { correlations between MSNQ and tests of } \\
\text { depression were higher than with } \\
\text { neuropsychological testing.' (p. 944) } \\
\text { (Benedict et al. 2008) }\end{array}$ & \\
\hline & $\begin{array}{l}\text { 'The test has excellent internal } \\
\text { consistency and test-retest reliability } \\
\text { (Benedict et al. 2003; Benedict et al. } \\
\text { 2004)(p. 575) (Carone et al. 2005) }\end{array}$ & $\begin{array}{l}\text { MSNQ Discrepancy scores for all MS } \\
\text { patients: } \\
\text { Underestimator group: } 16-30(\mathrm{M}=21.1 \text {, } \\
\text { SD=3.6) } \\
\text { Accurate estimator group: }-4-11 \\
\text { (M=2.4, SD=4.2) } \\
\text { Overestimator group: }-37 \text { - }-11(\mathrm{M}=- \\
\text { 20.6, } \mathrm{SD}=7.4) \\
\text { MSNQ Discrepancy scores for } \\
\text { cognitively impaired MS patients: } \\
\text { Underestimator group: } 16-30 \\
\text { (M=20.6, SD=4.3) } \\
\text { Accurate estimator group: }-3-10 \\
\text { (M=2.5, SD=4.0) } \\
\text { Overestimator group: }-37--11(\mathrm{M}=- \\
\text { 20.4, SD=7.5) }\end{array}$ & $\begin{array}{l}\text { 'While the validity of such informant } \\
\text { report questionnaire responses is } \\
\text { demonstrated in MS (Benedict et al. } \\
\text { 2003), and other conditions (Koss et al. } \\
\text { 1993; McGlone et al. 1990); } \\
\text { Sunderland et al., 1983), it falls short of } \\
\text { actual observation and could be subject } \\
\text { to report bias on part of the informants'. } \\
\text { (p. 581) (Carone et al. 2005) }\end{array}$ \\
\hline
\end{tabular}




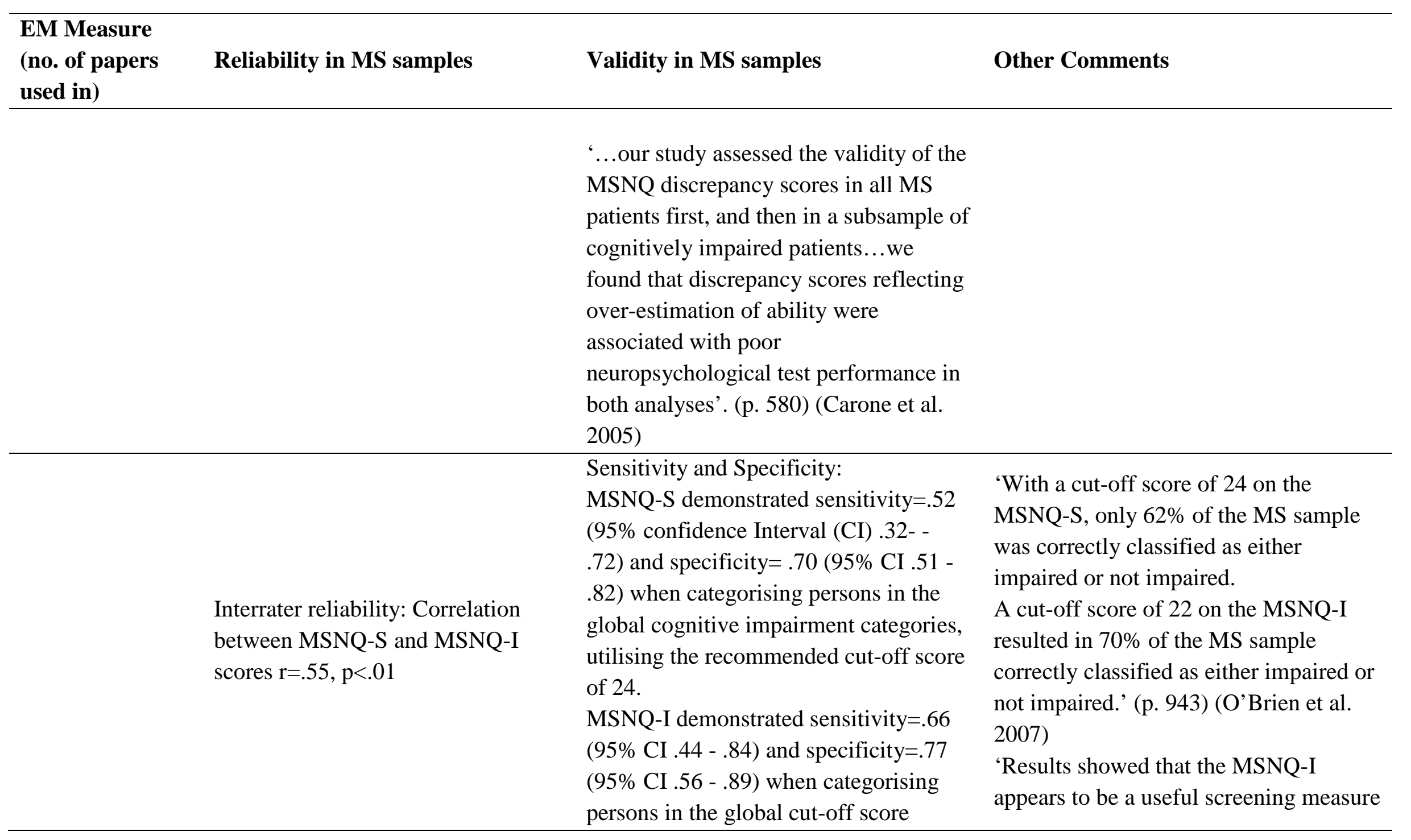




\begin{tabular}{|c|c|c|c|}
\hline $\begin{array}{l}\text { EM Measure } \\
\text { (no. of papers } \\
\text { used in) }\end{array}$ & Reliability in MS samples & Validity in MS samples & Other Comments \\
\hline & & $\begin{array}{l}\text { utilising the recommended cut-off score } \\
\text { of } 22 . \\
\text { ROC curve analysis: MSNQ-S, area } \\
\text { under ROC Curve is } .62 \% \text { (S.E. }=.09, \mathrm{p}> \\
.05 \text { ). This value was not significant. } \\
\text { In the current study, a score of } 7.5 \text { on } \\
\text { the MSNQ-S produced maximum } \\
\text { sensitivity (.90) and specificity (.96) for } \\
\text { this measure. } \\
\text { MSNQ-I, area under ROC curve is .74 } \\
\text { (S.E=.08, p> .05. This did not provide a } \\
\text { strong support for the ability to } \\
\text { differentiate between cognitively } \\
\text { impaired and non-impaired groups. In } \\
\text { this current study, a score of } 10 \text { on the } \\
\text { MSNQ-I produced the maximum } \\
\text { sensitivity (.94) and specificity (.55) for } \\
\text { this measure. (p.943-45) (O'Brien et al. } \\
\text { 2007) }\end{array}$ & $\begin{array}{l}\text { for cognitive impairment in persons with } \\
\text { MS'. (p. 945) (O’Brien et al. 2007) }\end{array}$ \\
\hline & Not Reported & Not Reported & \\
\hline & Not Reported & Not Reported & $\begin{array}{l}\text { 'Of note is that both self and informant } \\
\text { MSNQ findings did discriminate } \\
\text { between the MS and healthy control }\end{array}$ \\
\hline
\end{tabular}




\begin{tabular}{|c|c|c|c|}
\hline $\begin{array}{l}\text { EM Measure } \\
\text { (no. of papers } \\
\text { used in) }\end{array}$ & Reliability in MS samples & Validity in MS samples & Other Comments \\
\hline & & & $\begin{array}{l}\text { groups at both baseline and follow-up'. } \\
\text { (p.150) (Walker et al. 2016) }\end{array}$ \\
\hline \multirow[t]{5}{*}{ PRMQ (5) } & Not Reported & Not Reported & $\begin{array}{l}\text { (post hoc rationale) 'One can also } \\
\text { question the reliability of the answers } \\
\text { given on the PRMQ. However there are } \\
\text { two arguments in favour of the } \\
\text { reliability of the data. On the one hand, } \\
\text { there is the effect size... on the other } \\
\text { hand, there is convergence between } \\
\text { some of our results and those obtained } \\
\text { by others...' (p. 732-733) (Demers et al. } \\
\text { 2011) }\end{array}$ \\
\hline & $\begin{array}{l}\text { Cronbach's alpha } 0.89,0.84,0.80 \\
\text { (p. 401) }\end{array}$ & Not Reported & \\
\hline & Not Reported & Not Reported & $\begin{array}{l}\text { 'The PRMQ can be broken down into } \\
\text { prospective and retrospective memory } \\
\text { factors... given a very high correlation } \\
\text { between these factors (r>.80)' (p. 41) } \\
\text { (Bruce et al. 2010) }\end{array}$ \\
\hline & Not Reported & Not Reported & \\
\hline & Not Reported & Not Reported & \\
\hline RBMT (3) & Not Reported & $\begin{array}{l}\text { 'Furthermore, this test has been } \\
\text { validated by five to ten years follow ups }\end{array}$ & $\begin{array}{l}\text { 'The RBMT has shown to correlate well } \\
\text { to results of traditional memory tests }\end{array}$ \\
\hline
\end{tabular}




\begin{tabular}{|c|c|c|c|}
\hline $\begin{array}{l}\text { EM Measure } \\
\text { (no. of papers } \\
\text { used in) }\end{array}$ & Reliability in MS samples & Validity in MS samples & Other Comments \\
\hline & & $\begin{array}{l}\text { of patients with memory problems, thus } \\
\text { showing a close association between } \\
\text { test performance and independence } \\
\text { and/or employment' (Wilson et al. } \\
\text { 1991) (p.161) ( Haupts et al. 1994) }\end{array}$ & $\begin{array}{l}\text { such as the Wechsler Memory scale and } \\
\text { subjects' self-assessment } \\
\text { reports'(Lincoln \& Tinson, 1989) } \\
\text { (p.161) (Haupts et al. 1994) }\end{array}$ \\
\hline & Not Reported & Not Reported & \\
\hline & Not Reported & Not Reported & $\begin{array}{l}\text { 'It evaluates the mnemic function } \\
\text { understood in its 'ecological' sense'. (p. } \\
\text { 189) (Cutajar et al. 2000) }\end{array}$ \\
\hline \multirow{3}{*}{ Virtual Week (4) } & $\begin{array}{l}\text { Split half reliability of tasks for MS } \\
\text { group: regular (.85), irregular (.71), } \\
\text { time check (7.1) (.79, .75, .73 for } \\
\text { controls) (p. 742) (Rendell et al. } \\
\text { 2012) }\end{array}$ & Not Reported & $\begin{array}{l}\text { 'Virtual Week is a laboratory measure } \\
\text { of PM that closely represents the types } \\
\text { of PM tasks that actually occur in } \\
\text { everyday life' (p. 739) (Rendell et al. } \\
\text { 2012) }\end{array}$ \\
\hline & Not Reported & Not Reported & $\begin{array}{l}\text { 'It has been found to be very sensitive to } \\
\text { the effects of ageing on prospective } \\
\text { memory (Rendell \& Craik, 2000) and } \\
\text { also discriminates between patients with } \\
\text { bipolar disorder and healthy controls' ( } \\
\text { Rendell et al. 2012) (p. 411) (Rendell et } \\
\text { al. 2007) }\end{array}$ \\
\hline & Not Reported & Not Reported & \\
\hline
\end{tabular}




\begin{tabular}{|c|c|c|c|}
\hline $\begin{array}{l}\text { EM Measure } \\
\text { (no. of papers } \\
\text { used in) }\end{array}$ & Reliability in MS samples & Validity in MS samples & Other Comments \\
\hline & Not Reported & Not Reported & $\begin{array}{l}\text { '...this board game has been found to be } \\
\text { sensitive to PM deficits in other } \\
\text { populations, as well...' (p747) } \\
\text { (Kardiasmenos et al. 2008) }\end{array}$ \\
\hline \multirow[t]{2}{*}{ CFQ (2) } & $\begin{array}{l}\text { Cronbach's alpha was 0.95. (p. 103) } \\
\text { (Phillips et al. 2009) }\end{array}$ & Not Reported & $\begin{array}{l}\text { 'There are also indicators from previous } \\
\text { studies that the CFQ and ERQ are } \\
\text { associated with objective indicators of } \\
\text { performance' (see Robertson et al. } \\
\text { 1997) (TBI study)). (p. 104) (Phillips et } \\
\text { al. 2009) }\end{array}$ \\
\hline & Not Reported & Not Reported & \\
\hline \multirow{2}{*}{ MFQ (4) } & Not Reported & Not Reported & $\begin{array}{l}\text { 'The dependant variable used in these } \\
\text { analyses was the Total MFQ score, } \\
\text { which has a possible range of } 64 \text { (lowest } \\
\text { rating of one's memory faculties) to } 448 \\
\text { (highest rating).' (p. 558) (Krch et al. } \\
\text { 2011) }\end{array}$ \\
\hline & $\begin{array}{l}\text { 'internal consistency of factors } \\
\text { ranging from } 0.84 \text { to } 0.94 \\
\text { across'(Gilewski et al. 1990; } \\
\text { Zelinski et al. 1990) (p. 265) } \\
\text { (Randolph et al. 2004) }\end{array}$ & $\begin{array}{l}\text { '...has demonstrated concurrent validity } \\
\text { with memory performance measures } \\
\text { and convergent validity with another } \\
\text { commonly used metamemory measure'. } \\
\text { (Zelinski et al. 1990; Hertzog et al. } \\
\text { 1989) (p. 265) (Randolph et al. 2004) }\end{array}$ & $\begin{array}{l}\text { 'Associations were found between MFQ } \\
\text { scales and various measures of } \\
\text { depression and cognitive functioning...' } \\
\text { (p. 275) (Randolph et al. 2004) }\end{array}$ \\
\hline
\end{tabular}




\begin{tabular}{|c|c|c|c|}
\hline $\begin{array}{l}\text { EM Measure } \\
\text { (no. of papers } \\
\text { used in) }\end{array}$ & Reliability in MS samples & Validity in MS samples & Other Comments \\
\hline & Not Reported & Not Reported & \\
\hline & Not Reported & Not Reported & \\
\hline $\begin{array}{l}\text { CAMPROMPT } \\
\text { (1) }\end{array}$ & $\begin{array}{l}\text { 'Excellent interrater reliability (r= } \\
.99) \text {, adequate test-retest reliability } \\
\text { over 7-10 days (Kendall's Tau-b= } \\
.64) . \text { ' (p. 158) (Honan et al. 2015) }\end{array}$ & $\begin{array}{l}\text { The CAMPROMPT 'is an ecologically } \\
\text { valid 25-min measure of prospective } \\
\text { memory' (p, 158) (Honan et al. 2015) }\end{array}$ & $\begin{array}{l}\text { The CAMPROMPT 'is moderately } \\
\text { correlated with other measures of } \\
\text { memory, attention and executive } \\
\text { functioning (Wilson et al., 2005), and } \\
\text { can also distinguish the performance of } \\
\text { those with MS from healthy } \\
\text { controls'(Foley et al. 2004) (p. 158) } \\
\text { (Honan et al. 2015) }\end{array}$ \\
\hline \multirow[t]{2}{*}{ MIST (2) } & Not Reported & Not Reported & $\begin{array}{l}\text { The MIST 'demonstrates strong } \\
\text { psychometric properties and has been } \\
\text { shown to accurately reflect prospective } \\
\text { memory in a variety of neurologic } \\
\text { patient populations'(Woods et al. 2008; } \\
\text { Raskin et al. 2009) (p. 401) (Thelen et } \\
\text { al. 2014) }\end{array}$ \\
\hline & $\begin{array}{l}\text { Not reported for the current sample } \\
\text { 'The research version of the MIST } \\
\text { shows strong evidence of } \\
\text { reliability'(Woods et al. 2008) (p. } \\
\text { 890) (Miller et al. 2014) }\end{array}$ & $\begin{array}{l}\text { Not reported for the current sample } \\
\text { '...and construct validity '(Gupat et al } \\
.2010)(\text { p.890) (Miller et al. 2010) }\end{array}$ & $\begin{array}{l}\text { 'As such the current study extends the } \\
\text { external validity of the initial findings.' } \\
\text { (p. 892) }\end{array}$ \\
\hline
\end{tabular}




\begin{tabular}{|c|c|c|c|}
\hline $\begin{array}{l}\text { EM Measure } \\
\text { (no. of papers } \\
\text { used in) }\end{array}$ & Reliability in MS samples & Validity in MS samples & Other Comments \\
\hline MRS-C (1) & Not Reported & Not Reported & $\begin{array}{l}\text { 'Adapted from the Everyday Memory } \\
\text { Questionnaire, the MRS-C is composed } \\
\text { of } 31 \text { items that ask participants to } \\
\text { compare their current ability to } \\
\text { remember day-to-day information with } \\
\text { that of the average person'. (Sunderland } \\
\text { et al. 1983) (p. 204) Bruce \& Arnett } \\
\text { 2004) }\end{array}$ \\
\hline \multirow[t]{4}{*}{ PDQ (8) } & Not Reported & Not Reported & \\
\hline & Not Reported & Not Reported & $\begin{array}{l}\text { 'The reliability and validity of the } \\
\text { MSQLI (Fischer et al. 1999) and PDQ } \\
\text { have been shown in patients with MS' } \\
\text { (Marrie et al. 2003) (p. 103) (Mäntynen } \\
\text { et al. 2014) }\end{array}$ \\
\hline & Not Reported & Not Reported & \\
\hline & $\begin{array}{l}\text { 'The PDQ has good reliability...in } \\
\text { persons with MS (Cronbach's alpha } \\
\text { for five item PDQ reported between } \\
0.77-0.97 \text { ' (Fischer et al. 1999; } \\
\text { Marrie et al. 2003) (p. } \\
\text { 616)(Christodoulou et al. 2005) }\end{array}$ & $\begin{array}{l}\text { 'The PDQ has good....validity in } \\
\text { persons with MS...'(p.616) } \\
\text { (Christodoulou et al. 2005) }\end{array}$ & \\
\hline
\end{tabular}




\begin{tabular}{|c|c|c|c|}
\hline \multirow[t]{5}{*}{$\begin{array}{l}\text { EM Measure } \\
\text { (no. of papers } \\
\text { used in) }\end{array}$} & $\begin{array}{l}\text { Reliability in MS samples } \\
\text { Test-retest reliability r=.564, } \mathrm{p}<.001 \\
\text { (p.616) (Christodoulou et al. } 2005 \text { ) } \\
\end{array}$ & Validity in MS samples & Other Comments \\
\hline & Not Reported & Not Reported & \\
\hline & Not Reported & $\begin{array}{l}\text { 'Since the PDQ did not correlate with } \\
\text { any of the objective cognitive tests used } \\
\text { in this study, what the PDQ actually } \\
\text { assesses is uncertain.' (p. 81) (Lovera et } \\
\text { al. 2006) }\end{array}$ & \\
\hline & Not Reported & Not Reported & $\begin{array}{l}\text { 'Reports of cognitive concerns on the } \\
\text { PDQ were highly correlated with } \\
\text { concomitant reports of depression, } \\
\text { anxiety, fatigue and self-efficacy, in line } \\
\text { with existing literature' (Lovera et al } \\
\text { 2006; Kinsinger et al. 2010; Lester et al. } \\
\text { 2007). (p. 187) (Strober et al. 2016) }\end{array}$ \\
\hline & $\begin{array}{l}\text { The } 4 \text { subscales were internally } \\
\text { consistent: attention/concentration } \\
\text { (Cronbach's alpha)=.78, } \\
\text { planning/organization (Cronbach's } \\
\text { alpha) }=.84 \text {, retrospective memory } \\
\text { (Cronbach's alpha)=.83, prospective } \\
\text { memory (Cronbach's alpha)=.76. }\end{array}$ & $\begin{array}{l}\text { 'Concerns have been raised about the } \\
\text { validity of self-report measures of } \\
\text { cognitive functioning' (Herrman et al. } \\
\text { 1984) } \\
\text { 'For example, the current findings } \\
\text { indicate that individuals with MS } \\
\text { reported experiencing difficulties in }\end{array}$ & $\begin{array}{l}\text { 'The results of the survey also indicated } \\
\text { a high prevalence of spontaneous } \\
\text { utilisation of strategies to deal with } \\
\text { cognitive difficulties. The most } \\
\text { commonly reported strategy was a use } \\
\text { of an external memory aid.' (p. 103) } \\
\text { (Sullivan et al. 1990) }\end{array}$ \\
\hline
\end{tabular}




\begin{tabular}{|c|c|c|c|}
\hline $\begin{array}{l}\text { EM Measure } \\
\text { (no. of papers } \\
\text { used in) }\end{array}$ & Reliability in MS samples & Validity in MS samples & Other Comments \\
\hline & $\begin{array}{l}\text { Inter-factor correlations } \\
\text { averaged }=.45\end{array}$ & $\begin{array}{l}\text { prospective memory, and planning and } \\
\text { organization'. } \\
\text { 'The validity of self-report measures of } \\
\text { cognitive problems may best be } \\
\text { addressed by examining whether these } \\
\text { measures predict disruptions in daily } \\
\text { living, not whether they predict } \\
\text { neuropsychological test scores'. (p.103) } \\
\text { (Sullivan et al. 1990) }\end{array}$ & \\
\hline $\begin{array}{l}\text { Self-evaluation of } \\
\text { everyday memory } \\
\text { and learning (1) }\end{array}$ & Not Reported & Not Reported & $\begin{array}{l}\text { From personal communications with } \\
\text { author (24th August 2016) this was a } \\
\text { unitary scale that was self-administered. } \\
\text { No psychometric properties were } \\
\text { available. }\end{array}$ \\
\hline \multicolumn{4}{|c|}{$\begin{array}{l}\text { Note. Abbreviations: BDI-FS: Beck Depression Inventory-Fast Screen; BRBN: Brief Repeatable Battery of Neuropsychological Tests; CAMPROMPT: } \\
\text { Cambridge Prospective Memory Test; CFQ: Cognitive Failures Questionnaire; EM: Everyday memory; EMQ: Everyday Memory Questionnaire; ERQ: } \\
\text { Emotion Regulation Questionnaire; HADS: Hospital Anxiety and Depression Scale; MFQ: Memory Functioning Questionnaire; MIST: Memory for Intention } \\
\text { Screening Test; MRS: Memory Rating Scale; MS: Multiple Sclerosis; MSNQ: MS Neuropsychological Questionnaire (MSNQ-P: patient self-report version; } \\
\text { MSNQ-I: Informant version); MSQLI: Multiple Sclerosis Quality of Life Inventory; PDQ: Perceived Deficits Questionnaire; PM: Prospective memory; } \\
\text { PRMQ: Prospective and Retrospective Memory Questionnaire; RBMT: Rivermead Behavioural Memory Test; ROC: Receiver Operating Characteristic; } \\
\text { SDMT: Symbol Digit Modalities Test; TBI: Traumatic Brain Injury. }\end{array}$} \\
\hline
\end{tabular}




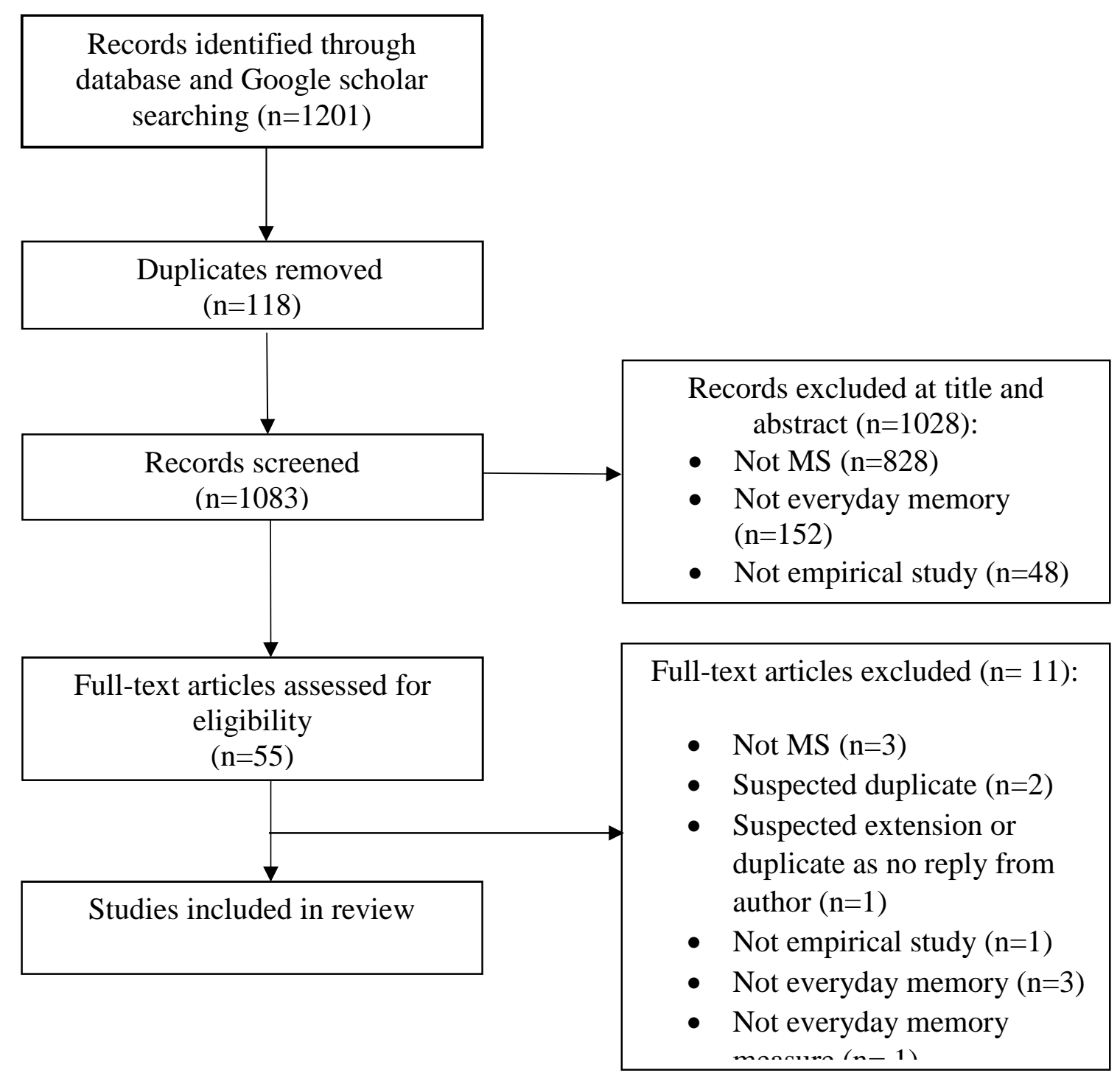

Figure 1. PRISMA flowchart for searches. 


\section{Supplementary Materials}

A: OVID Search Strategy

1. MS/

2. disseminated sclerosis/

3. multiple sclerosis/

4. Everyday memory/

5. daily memory/

6. real life memory/

7. Everyday memory questionnaire/

8. cognitive failures questionnaire/

9. multifactorial memory questionnaire/

10. memory failures of everyday/

11. comprehensive assessment of prospective memory/

12. memory functioning questionnaire/

13. prospective and retrospective memory questionnaire/

14. memory rating scale/

15. subjective memory rating scale/

16. subjective memory complaint clinical/

17. subjective memory questionnaire/

18. memory assessment clinics self-rating scale/

19. memory assessment clinics questionnaire/

20. questionnaire or memory efficiency/

21. memory complain questionnaire/

22. self-efficacy questionnaire/

23. memory self-report questionnaire/

24. memory observation questionnaire/

25. memory problem questionnaire/

26. short memory questionnaire/

27. computerized everyday memory battery/

28. Rivermead behavioural memory test/

29. Cambridge prospective memory test/

30. virtual week/

31. everyday memory interview/

32. 1 or 2 or 3

33. 4 or 5 or 6 or 7 or 8 or 9 or 10 or 11 or 12 or 13 or 14 or 15 or 16 or 17 or 18 or 19 or 20 or 21 or 22 or 23 or 24 or 25 or 26 or 27 or 28 or 29 or 30 or 31

34. 32 and 33 


\section{B: Data extraction form}

\begin{tabular}{|l|l|l|l|}
\hline Reviewer: & Date: & \\
\hline Author: & & \\
\hline Year: & & Journal: & \\
\hline Country: & & \\
\hline Record Number: & & \\
\hline
\end{tabular}

STUDY METHOD

RCT

$\square$ QUASI-RCT

LONGITUDINAL

RETROSPECTIVE

OBSERVATIONAL

CASE STUDY

COHORT STUDY

OTHER

PARTICIPANTS DEMOGRAPHICS

Population:

Sample size:

Gender (\%F):

Age:

MS Type (No):

Education (Years):

Ethnicity:

AIM

MEASURES

USE OF MEASURE

RELIABILITY

VALIDITY

REVIEWERS NOTES AND CONCLUSIONS 
C: Sample demographics and EM measure details.

\begin{tabular}{|c|c|c|c|c|c|c|c|c|c|c|}
\hline \multirow{2}{*}{$\begin{array}{c}\text { Paper } \\
\#\end{array}$} & \multirow{2}{*}{$\begin{array}{l}\text { Author / } \\
\text { Year / } \\
\text { Country }\end{array}$} & \multicolumn{6}{|c|}{ MS group } & \multirow[b]{2}{*}{ EM Measure(s) } & \multicolumn{2}{|c|}{ Use of Measure } \\
\hline & & Sample Size & $\begin{array}{l}\text { Gender } \\
(\% F)\end{array}$ & Age (years) & $\begin{array}{l}\text { Education } \\
\text { (years) }\end{array}$ & Ethnicity & MS Type & & $\begin{array}{l}\text { How } \\
\text { Administered }\end{array}$ & Why used \\
\hline 1 & $\begin{array}{l}\text { Chipchase \& } \\
\text { Lincoln } \\
(2001) \\
\text { UK }\end{array}$ & $\begin{array}{l}51 \\
\text { (informal } \\
\text { carers= } \\
51 \text { ) }\end{array}$ & 58 & $\begin{array}{l}M=44 \\
S D=9.41 \\
\text { Range= 26- } \\
64\end{array}$ & Not Reported & $\begin{array}{l}\text { Not } \\
\text { Reported }\end{array}$ & Not Reported & EMQ & $\begin{array}{l}\text { Postal } \\
\text { administration } \\
\text { at } 2 \text { time points } \\
\text { (baseline \& } 4 \\
\text { months after } \\
\text { recruitment) }\end{array}$ & $\begin{array}{l}\text { As a predictor } \\
\text { variable for carer } \\
\text { strain }\end{array}$ \\
\hline 2 & $\begin{array}{l}\text { Haupts et al. } \\
\text { (1994) } \\
\text { Germany }\end{array}$ & $\begin{array}{l}35 \\
\text { (healthy } \\
\text { controls= } \\
30)\end{array}$ & 63 & $\begin{array}{l}\mathrm{M}=35.9 \\
\mathrm{SD}=+/-7 \\
\text { Range=21-61 }\end{array}$ & $\begin{array}{l}\text { 'Education } \\
\text { was scored in } \\
\text { levels of } \\
\text { formal } \\
\text { education...' } \\
\text { (p. 159) Not } \\
\text { reported in } \\
\text { years }\end{array}$ & $\begin{array}{l}\text { Not } \\
\text { Reported }\end{array}$ & $\begin{array}{l}F M=6 \\
R R=20 \\
P P=9\end{array}$ & German RBMT & $\begin{array}{l}\text { Face to face } \\
\text { inferred. } \\
\text { Administration } \\
\text { at one time } \\
\text { point }\end{array}$ & $\begin{array}{l}\text { To compare EM } \\
\text { tasks between MS } \\
\text { and control groups }\end{array}$ \\
\hline 3 & $\begin{array}{l}\text { Honan et al. } \\
\text { (2015) } \\
\text { Australia }\end{array}$ & 111 & 70 & $\begin{array}{l}\text { In paid } \\
\text { employment } \\
M=44.34 \\
S D=10.35 \\
\text { unemployed } \\
M=50.94 \\
S D=10.53\end{array}$ & $\begin{array}{l}\text { Expressed } \\
\text { according to } \\
\text { employment } \\
\text { status } \\
\text { In paid } \\
\text { employment }\end{array}$ & $\begin{array}{l}\text { Not } \\
\text { Reported }\end{array}$ & $\begin{array}{l}\text { In paid } \\
\text { employment } \\
\mathrm{RR}=46 \\
\mathrm{SP}=10 \\
\mathrm{PP}=3 \\
\text { Other=3 } \\
\text { unemployed }\end{array}$ & CAMPROMPT & $\begin{array}{l}\text { Face to face } \\
\text { inferred. } \\
\text { Administration } \\
\text { at one time } \\
\text { point }\end{array}$ & $\begin{array}{l}\text { As a predictor } \\
\text { variable for work } \\
\text { outcomes }\end{array}$ \\
\hline
\end{tabular}




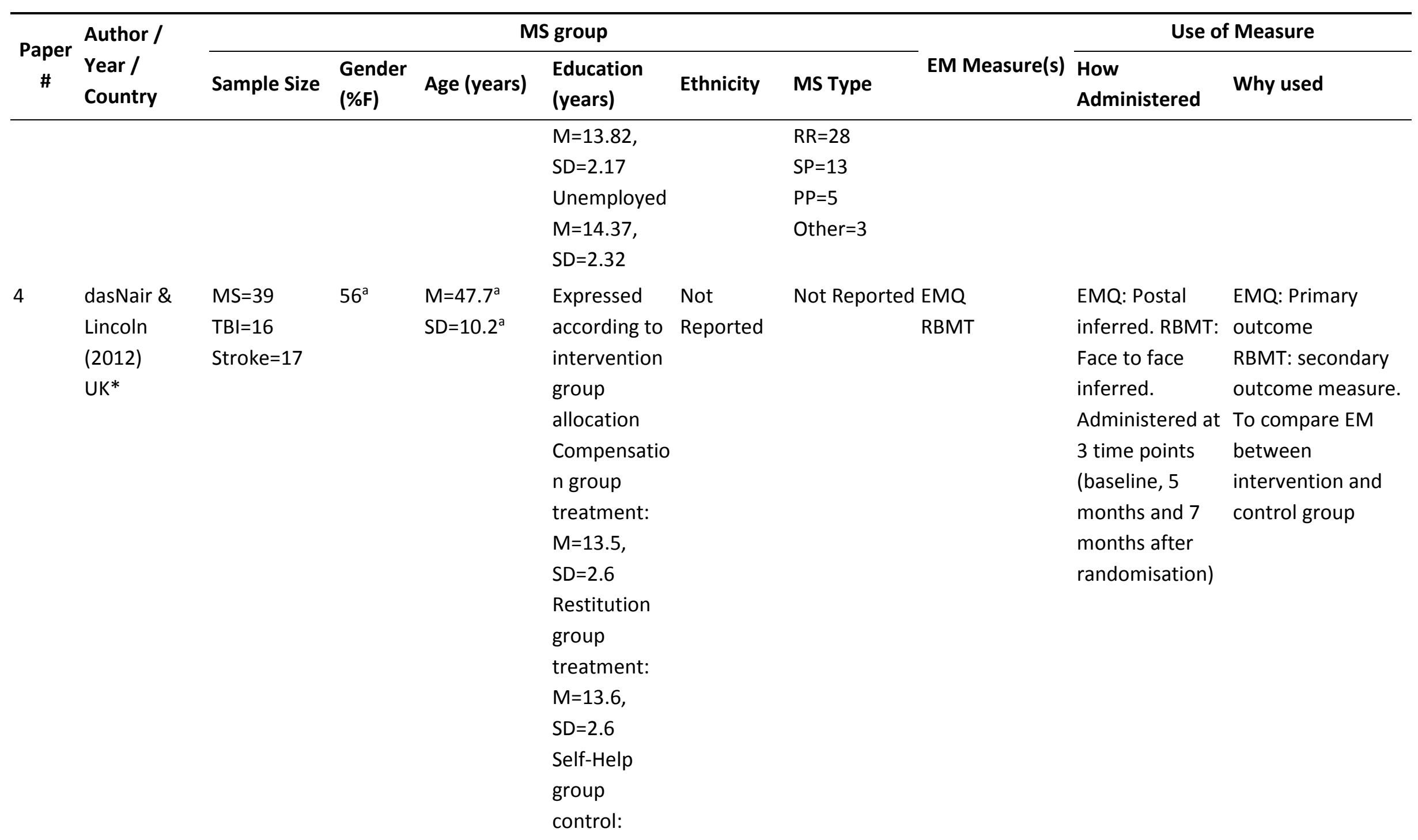




\begin{tabular}{|c|c|c|c|c|c|c|c|c|c|c|}
\hline \multirow{2}{*}{$\begin{array}{c}\text { Paper } \\
\#\end{array}$} & \multirow{2}{*}{$\begin{array}{l}\text { Author / } \\
\text { Year / } \\
\text { Country }\end{array}$} & \multicolumn{6}{|c|}{ MS group } & \multirow[b]{2}{*}{ EM Measure(s) } & \multicolumn{2}{|c|}{ Use of Measure } \\
\hline & & Sample Size & $\begin{array}{l}\text { Gender } \\
\text { (\%F) }\end{array}$ & Age (years) & $\begin{array}{l}\text { Education } \\
\text { (years) }\end{array}$ & Ethnicity & MS Type & & $\begin{array}{l}\text { How } \\
\text { Administered }\end{array}$ & Why used \\
\hline & & & & & $\begin{array}{l}\mathrm{M}=12.4 \\
\mathrm{SD}=2.1^{\mathrm{a}}\end{array}$ & & & & & \\
\hline 5 & $\begin{array}{l}\text { Rendell et al. } \\
\text { (2012) } \\
\text { Australia }\end{array}$ & $\begin{array}{l}30 \\
\text { (healthy } \\
\text { controls= } \\
30 \text { ) }\end{array}$ & 80 & $\begin{array}{l}\mathrm{M}=47 \\
\mathrm{SD}=9.46 \\
\text { Range }=28-60\end{array}$ & $\begin{array}{l}M=14.2 \\
S D=3.14\end{array}$ & $\begin{array}{l}\text { Not } \\
\text { Reported }\end{array}$ & \multicolumn{2}{|c|}{ Not Reported Virtual Week } & $\begin{array}{l}\text { Computer } \\
\text { administration } \\
\text { in the lab at one } \\
\text { time point }\end{array}$ & $\begin{array}{l}\text { To compare PM } \\
\text { between MS and } \\
\text { controls across } \\
\text { positive, negative } \\
\text { and neutral } \\
\text { emotional task } \\
\text { conditions }\end{array}$ \\
\hline 6 & $\begin{array}{l}\text { Krch et al. } \\
(2011) \\
\text { USA }\end{array}$ & 64 & 75 & $\begin{array}{l}\mathrm{M}=47.7 \\
\mathrm{SD}=+/-9.3 \\
\text { Range }=18-55\end{array}$ & $\begin{array}{l}M=15.7 \\
S D=+/-2.4\end{array}$ & $\begin{array}{l}\text { Not } \\
\text { Reported }\end{array}$ & $\begin{array}{l}\mathrm{RR}=47 \\
\mathrm{PP}=2 \\
\mathrm{SP}=1 \\
\text { Unknown=1 }\end{array}$ & MFQ & $\begin{array}{l}\text { Administration } \\
\text { method not } \\
\text { reported. } \\
\text { Administered at } \\
\text { one time point }\end{array}$ & $\begin{array}{l}\text { To correlate } \\
\text { subjective memory } \\
\text { with other } \\
\text { cognitive tests } \\
\text { (objective memory) }\end{array}$ \\
\hline 7 & $\begin{array}{l}\text { Phillips et al. } \\
\text { (2009) } \\
\text { UK }\end{array}$ & 86 & 73 & $\begin{array}{l}\mathrm{M}=44.8 \\
\mathrm{SD}=8.9 \\
\text { Range }=27-67\end{array}$ & Not Reporte & $\begin{array}{l}\text { Not } \\
\text { Reported }\end{array}$ & $\begin{array}{l}\mathrm{RR}=61 \\
\mathrm{PP}=17 \\
\text { Not } \\
\text { Recorded }=8\end{array}$ & CFQ & $\begin{array}{l}\text { Postal } \\
\text { administration } \\
\text { at one time } \\
\text { point }\end{array}$ & $\begin{array}{l}\text { As a predictor } \\
\text { variable for Quality } \\
\text { of Life (QoL), } \\
\text { measuring self- } \\
\text { reported failures of } \\
\text { attention }\end{array}$ \\
\hline 8 & $\begin{array}{l}\text { Royle \& } \\
\text { Lincoln } \\
\text { (2008) }\end{array}$ & $\begin{array}{l}160 \\
\text { (Stroke } \\
\text { patients= }\end{array}$ & 70 & $\begin{array}{l}M=43 \\
S D=11 \\
\text { Range=17-71 }\end{array}$ & Not Reporte & $\begin{array}{l}\text { Not } \\
\text { Reported }\end{array}$ & Not Reported & EMQ & $\begin{array}{l}\text { Not reported } \\
\text { 'Data were } \\
\text { drawn from two }\end{array}$ & $\begin{array}{l}\text { To analyse the } \\
\text { internal } \\
\text { consistency and }\end{array}$ \\
\hline
\end{tabular}




\begin{tabular}{|c|c|c|c|c|c|c|c|c|c|c|}
\hline \multirow{2}{*}{$\begin{array}{c}\text { Paper } \\
\#\end{array}$} & \multirow{2}{*}{$\begin{array}{l}\text { Author / } \\
\text { Year / } \\
\text { Country }\end{array}$} & \multicolumn{6}{|c|}{ MS group } & \multirow[b]{2}{*}{ EM Measure(s) } & \multicolumn{2}{|c|}{ Use of Measure } \\
\hline & & Sample Size & $\begin{array}{l}\text { Gender } \\
\text { (\%F) }\end{array}$ & Age (years) & $\begin{array}{l}\text { Education } \\
\text { (years) }\end{array}$ & Ethnicity & MS Type & & $\begin{array}{l}\text { How } \\
\text { Administered }\end{array}$ & Why used \\
\hline & UK & $\begin{array}{l}\text { 90, Healthy } \\
\text { Controls= } \\
98)\end{array}$ & & & & & & & $\begin{array}{l}\text { sources for } \\
\text { three groups' (p. } \\
116)\end{array}$ & $\begin{array}{l}\text { factor structure of } \\
\text { the EMQ }\end{array}$ \\
\hline 9 & $\begin{array}{l}\text { Lincoln et al. } \\
(2002) \\
\text { UK* }\end{array}$ & 223 & 70 & $\begin{array}{l}M=43 \\
S D=10\end{array}$ & $\begin{array}{l}\text { Control } \\
\text { Group age } 1 \epsilon \\
\text { Assessment } \\
\text { Group age } 16 \\
\text { Intervention } \\
\text { Group age } 16\end{array}$ & Not & $\begin{array}{l}\text { Control } \\
\text { Group } \\
\mathrm{SP}=35 \\
\mathrm{RR}=37 \\
\mathrm{PP}=6 \\
\text { Unknown=4 } \\
\text { Assessment } \\
\text { Group } \\
\mathrm{SP}=33 \\
\mathrm{RR}=35 \\
\mathrm{PP}=6 \\
\text { Unknown=5 } \\
\text { Intervention } \\
\mathrm{Group} \\
\mathrm{SP}=26 \\
\mathrm{RR}=35 \\
\mathrm{PP}=7 \\
\text { Unknown=12 }\end{array}$ & EMQ & $\begin{array}{l}\text { Face to face } \\
\text { inferred. } \\
\text { Administration } \\
\text { at } 2 \text { time points } \\
\text { ( } 4 \text { and } 8 \text { months } \\
\text { after } \\
\text { recruitment) }\end{array}$ & $\begin{array}{l}\text { Outcome measure. } \\
\text { To compare EM } \\
\text { between cognitive } \\
\text { assessment, } \\
\text { intervention and } \\
\text { control groups }\end{array}$ \\
\hline 10 & $\begin{array}{l}\text { Richardson } \\
\text { (1996) }\end{array}$ & 115 & 61 & $\begin{array}{l}M=48.5 \\
\text { Range=32-73 }\end{array}$ & Not Reportec & $\begin{array}{l}\text { Not } \\
\text { Reported }\end{array}$ & Not Reported & EMQ & $\begin{array}{l}\text { Postal } \\
\text { administration }\end{array}$ & $\begin{array}{l}\text { To classify people } \\
\text { with MS as }\end{array}$ \\
\hline
\end{tabular}




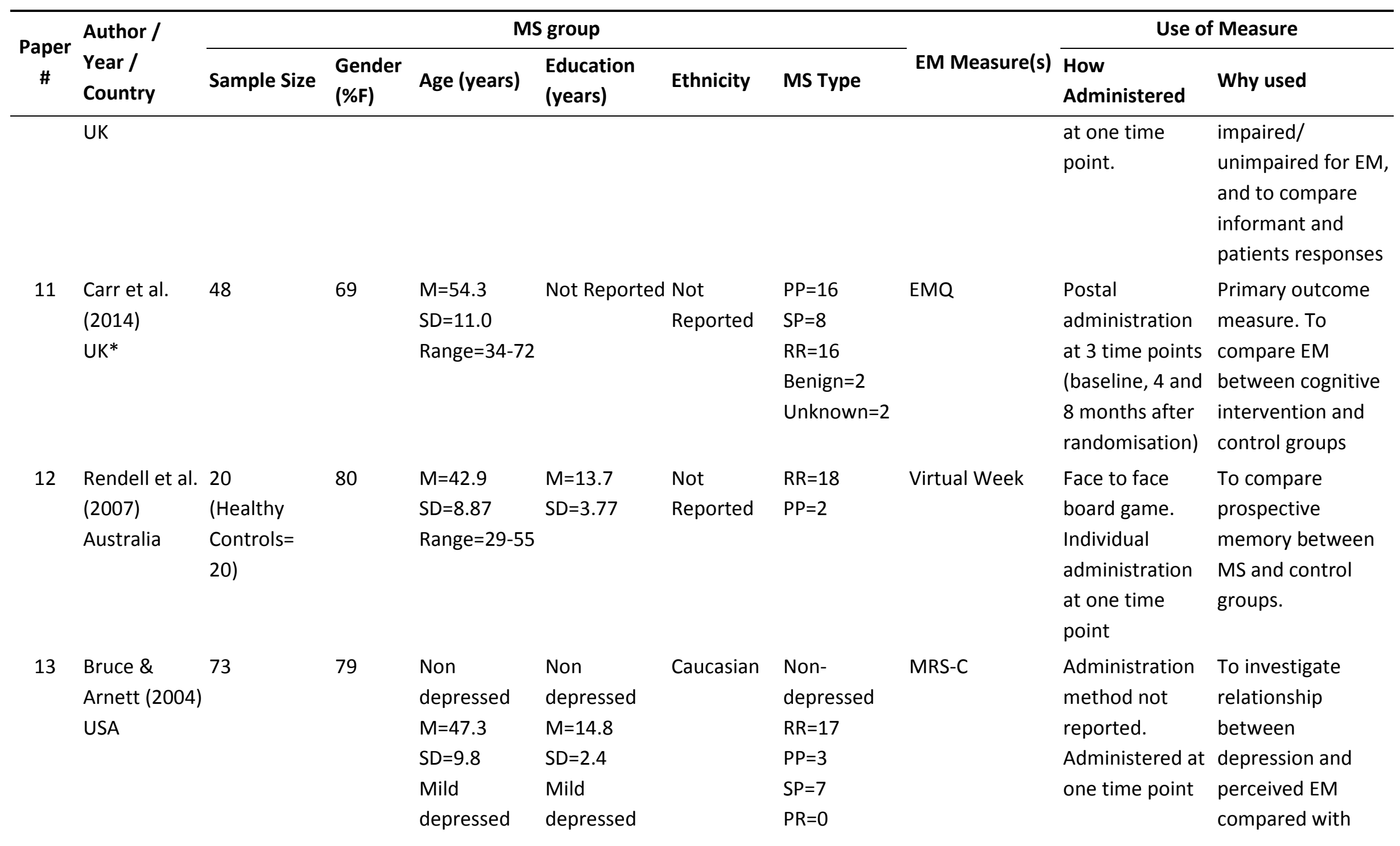




\begin{tabular}{|c|c|c|c|c|c|c|c|c|c|c|}
\hline \multirow{2}{*}{$\begin{array}{c}\text { Paper } \\
\quad \#\end{array}$} & \multirow{2}{*}{$\begin{array}{l}\text { Author / } \\
\text { Year / } \\
\text { Country }\end{array}$} & \multicolumn{6}{|c|}{ MS group } & \multirow[b]{2}{*}{ EM Measure(s) } & \multicolumn{2}{|c|}{ Use of Measure } \\
\hline & & Sample Size & $\begin{array}{l}\text { Gender } \\
\text { (\%F) }\end{array}$ & Age (years) & $\begin{array}{l}\text { Education } \\
\text { (years) }\end{array}$ & Ethnicity & MS Type & & $\begin{array}{l}\text { How } \\
\text { Administered }\end{array}$ & Why used \\
\hline & & & & $\begin{array}{l}\mathrm{M}=43.1 \\
\mathrm{SD}=6.9 \\
\text { Moderate } \\
\text { depressed } \\
\mathrm{M}=49.7 \\
\mathrm{SD}=6.4\end{array}$ & $\begin{array}{l}\mathrm{M}=14.9 \\
\mathrm{SD}=2.6 \\
\text { Moderate } \\
\text { depressed } \\
\mathrm{M}=14.9 \\
\mathrm{SD}=2.3\end{array}$ & & $\begin{array}{l}\text { Mild- } \\
\text { depressed } \\
R R=14 \\
P P=2 \\
S P=5 \\
P R=0 \\
\text { Moderate } \\
\text { depressed } \\
R R=15 \\
P P=2 \\
S P=6 \\
P R=2\end{array}$ & & & $\begin{array}{l}\text { depression and } \\
\text { objective memory }\end{array}$ \\
\hline 14 & $\begin{array}{l}\text { Randolph et } \\
\text { al. (2004) } \\
\text { USA }\end{array}$ & 48 & 77 & $\begin{array}{l}M=49.6 \\
S D=7.8\end{array}$ & $\begin{array}{l}M=15.1 \\
S D=2.3\end{array}$ & $\begin{array}{l}\text { Not } \\
\text { Reported }\end{array}$ & $\begin{array}{l}\mathrm{RR}=28 \\
\mathrm{SP}=13 \\
\mathrm{PP}=6 \\
\mathrm{PR}=1\end{array}$ & MFQ & $\begin{array}{l}\text { Face to face } \\
\text { inferred. } \\
\text { Administration } \\
\text { at one time } \\
\text { point }\end{array}$ & $\begin{array}{l}\text { To evaluate the } \\
\text { associations } \\
\text { between mood and } \\
\text { executive function } \\
\text { on metamemory } \\
\text { (MFQ) }\end{array}$ \\
\hline 15 & $\begin{array}{l}\text { Erlanger et } \\
\text { al. (2014) } \\
\text { USA }\end{array}$ & 60 & 72 & $\begin{array}{l}\mathrm{M}=47.9 \\
\mathrm{SD}=7.9 \\
\text { Range=26-61 }\end{array}$ & $\begin{array}{l}\text { Not High } \\
\text { school } \\
\text { graduate=2\% } \\
\text { High School } \\
\text { Degree=27\% }\end{array}$ & $\begin{array}{l}\text { Caucasian= } \\
87 \% \\
\text { African- } \\
\text { American=5 } \\
\%\end{array}$ & $\begin{array}{l}R R=46 \\
S P=14\end{array}$ & $\begin{array}{l}\text { MFQ } \\
\text { MSNQ }\end{array}$ & $\begin{array}{l}\text { Face to face } \\
\text { inferred. } \\
\text { Administered at } \\
\text { two time points } \\
\text { ( } 45 \text { days apart) }\end{array}$ & $\begin{array}{l}\text { To compare MFQ } \\
\text { and MSNQ (patient } \\
\text { and informant) } \\
\text { with another } \\
\text { cognitive test }\end{array}$ \\
\hline
\end{tabular}




\begin{tabular}{|c|c|c|c|c|c|c|c|c|c|c|}
\hline \multirow{2}{*}{$\begin{array}{c}\text { Paper } \\
\#\end{array}$} & \multirow{2}{*}{$\begin{array}{l}\text { Author / } \\
\text { Year / } \\
\text { Country }\end{array}$} & \multicolumn{6}{|c|}{ MS group } & \multirow[b]{2}{*}{ EM Measure(s) } & \multicolumn{2}{|c|}{ Use of Measure } \\
\hline & & Sample Size & $\begin{array}{l}\text { Gender } \\
\text { (\%F) }\end{array}$ & Age (years) & $\begin{array}{l}\text { Education } \\
\text { (years) }\end{array}$ & Ethnicity & MS Type & & $\begin{array}{l}\text { How } \\
\text { Administered }\end{array}$ & Why used \\
\hline & & & & & $\begin{array}{l}\text { Associate } \\
\text { Degree=18\% } \\
\text { Bachelor's } \\
\text { Degree=28\% } \\
\text { Master's } \\
\text { Degree=21\% } \\
\text { Advanced } \\
\text { Degree=5\% }\end{array}$ & $\begin{array}{l}\text { Hispanic=5 } \\
\% \\
\text { Other=3\% }\end{array}$ & & & & $\begin{array}{l}\text { (objective memory) } \\
\text { in order to } \\
\text { evaluate the } \\
\text { validity of the } \\
\text { objective memory } \\
\text { test, and to } \\
\text { compare } \\
\text { correlations } \\
\text { between MS type }\end{array}$ \\
\hline 16 & $\begin{array}{l}\text { Thelen et al. } \\
\text { (2014) } \\
\text { USA }\end{array}$ & 86 & 88 & $\begin{array}{l}M=47.17 \\
S D=+/-10.56\end{array}$ & $\begin{array}{l}M=14.9 \\
S D=+/-1.93\end{array}$ & $\begin{array}{l}\text { Caucasian= } \\
89.4 \% \\
\text { African- } \\
\text { American=5 } \\
.9 \% \\
\text { Hispanic/La } \\
\text { tino=3.5\% } \\
\text { Other=1.2\% }\end{array}$ & $\begin{array}{l}R R=75 \\
S P=9 \\
P P=2\end{array}$ & $\begin{array}{l}\text { PRMQ } \\
\text { MIST }\end{array}$ & $\begin{array}{l}\text { Face to face } \\
\text { inferred. } \\
\text { Administered at } \\
\text { one time point }\end{array}$ & $\begin{array}{l}\text { To compare EM } \\
\text { between MS } \\
\text { groups with } \\
\text { polypharmacy and } \\
\text { without } \\
\text { polypharmacy }\end{array}$ \\
\hline 17 & $\begin{array}{l}\text { Stuifbergen } \\
\text { et al. (2012) } \\
\text { USA* }\end{array}$ & 61 & 89 & Not Reported & $\begin{array}{l}\text { High } \\
\text { school=20 } \\
\text { Associate } \\
\text { degree=5 } \\
\text { Bachelor's } \\
\text { degree=19 }\end{array}$ & $\begin{array}{l}\text { White }=89 \% \\
\text { African- } \\
\text { American=3 } \\
\%\end{array}$ & Not Reporte & $\begin{array}{l}\text { MSNQ } \\
\text { PDQ }\end{array}$ & $\begin{array}{l}\text { MSNQ: } \\
\text { Administration } \\
\text { method not } \\
\text { reported. } \\
\text { Administered at } \\
3 \text { time points }\end{array}$ & $\begin{array}{l}\text { MSNQ: Outcome } \\
\text { measure. To } \\
\text { compare between } \\
\text { cognitive training } \\
\text { intervention and } \\
\text { control group }\end{array}$ \\
\hline
\end{tabular}




\begin{tabular}{|c|c|c|c|c|c|c|c|c|c|c|}
\hline \multirow{2}{*}{$\begin{array}{c}\text { Paper } \\
\quad \#\end{array}$} & \multirow{2}{*}{$\begin{array}{l}\text { Author / } \\
\text { Year / } \\
\text { Country }\end{array}$} & \multicolumn{6}{|c|}{ MS group } & \multirow[b]{2}{*}{ EM Measure(s) } & \multicolumn{2}{|c|}{ Use of Measure } \\
\hline & & Sample Size & $\begin{array}{l}\text { Gender } \\
\text { (\%F) }\end{array}$ & Age (years) & $\begin{array}{l}\text { Education } \\
\text { (years) }\end{array}$ & Ethnicity & MS Type & & $\begin{array}{l}\text { How } \\
\text { Administered }\end{array}$ & Why used \\
\hline & & & & & $\begin{array}{l}\text { Graduate } \\
\text { degree }=17\end{array}$ & $\begin{array}{l}\text { Multiple } \\
\text { categories= } \\
3 \% \\
\text { Other }=5 \%\end{array}$ & & & $\begin{array}{l}\text { (baseline, } 2 \text { and } \\
5 \text { months } \\
\text { follow-up) } \\
\text { PDQ: Telephone } \\
\text { administration } \\
\text { at one time } \\
\text { point (during } \\
\text { screening) }\end{array}$ & $\begin{array}{l}\text { PDQ: To screen for } \\
\text { eligibility to take } \\
\text { part based on } \\
\text { perceived deficits }\end{array}$ \\
\hline 18 & $\begin{array}{l}\text { Bruce et al. } \\
(2010) \\
\text { USA }\end{array}$ & $\begin{array}{l}79 \\
\text { (Healthy } \\
\text { Controls= } \\
20)\end{array}$ & 90 & $\begin{array}{l}M=47.2 \\
S D=10.82\end{array}$ & $\begin{array}{l}M=14.85 \\
S D=1.96\end{array}$ & $\begin{array}{l}\text { Caucasian= } \\
87 \% \\
\text { African- } \\
\text { American=6 } \\
\% \\
\text { Latino=4\% } \\
\text { Unspecified } \\
=3 \%\end{array}$ & $\begin{array}{l}\mathrm{RR}=71 \\
\mathrm{SP}=8\end{array}$ & PRMQ & $\begin{array}{l}\text { Face to face } \\
\text { inferred. } \\
\text { Administered at } \\
\text { one time point }\end{array}$ & $\begin{array}{l}\text { To correlate with } \\
\text { other cognitive } \\
\text { tests (objective } \\
\text { memory, executive } \\
\text { function, } \\
\text { information } \\
\text { processing) and } \\
\text { variables (mood } \\
\text { and dissociation) }\end{array}$ \\
\hline 19 & $\begin{array}{l}\text { Middleton et } \\
\text { al. (2006) } \\
\text { USA }\end{array}$ & $\begin{array}{l}221 \\
\text { (Healthy } \\
\text { Controls= } \\
31)\end{array}$ & 74 & $\begin{array}{l}\mathrm{M}=44.8 \\
\text { Range }=20-71\end{array}$ & $\begin{array}{l}M=14.8 \\
\text { Range=10-22 }\end{array}$ & $\begin{array}{l}\text { Not } \\
\text { Reported }\end{array}$ & $\begin{array}{l}\mathrm{RR}=65 \% \\
\mathrm{SP}=21 \% \\
\mathrm{PP}=12 \% \\
\mathrm{PR}=2 \%\end{array}$ & CFQ & $\begin{array}{l}\text { Face to face } \\
\text { administration } \\
\text { at home or in } \\
\text { clinic at one } \\
\text { time point }\end{array}$ & $\begin{array}{l}\text { To compare EM } \\
\text { between MS and } \\
\text { control groups, to } \\
\text { correlate with } \\
\text { other cognitive } \\
\text { tests (objective }\end{array}$ \\
\hline
\end{tabular}




\begin{tabular}{|c|c|c|c|c|c|c|c|c|c|c|}
\hline \multirow{2}{*}{$\begin{array}{c}\text { Paper } \\
\#\end{array}$} & \multirow{2}{*}{$\begin{array}{l}\text { Author / } \\
\text { Year / } \\
\text { Country }\end{array}$} & \multicolumn{6}{|c|}{ MS group } & \multirow[b]{2}{*}{ EM Measure(s) } & \multicolumn{2}{|c|}{ Use of Measure } \\
\hline & & Sample Size & $\begin{array}{l}\text { Gender } \\
\text { (\%F) }\end{array}$ & Age (years) & $\begin{array}{l}\text { Education } \\
\text { (years) }\end{array}$ & Ethnicity & MS Type & & $\begin{array}{l}\text { How } \\
\text { Administered }\end{array}$ & Why used \\
\hline & & & & & & & & & & $\begin{array}{l}\text { memory), and to } \\
\text { investigate other } \\
\text { variables } \\
\text { (education, } \\
\text { depression, } \\
\text { anxiety, fatigue } \\
\text { and disability) as } \\
\text { predictors of } \\
\text { perceived cognitive } \\
\text { function (CFQ) }\end{array}$ \\
\hline 20 & $\begin{array}{l}\text { West et al. } \\
\text { (2007) } \\
\text { USA }\end{array}$ & 1 & 100 & 71 & $\begin{array}{l}\text { Ed.D } \\
\text { (Doctorate in } \\
\text { Education) in } \\
\text { Psychology }\end{array}$ & $\begin{array}{l}\text { Not } \\
\text { Reported }\end{array}$ & $\mathrm{RR}=1$ & $\begin{array}{l}\text { PRMQ } \\
\text { Virtual Week }\end{array}$ & $\begin{array}{l}\text { Face to face } \\
\text { administration } \\
\text { at } 2 \text { time points } \\
\text { (1 year apart) }\end{array}$ & $\begin{array}{l}\text { Part of a battery of } \\
\text { tests to describe } \\
\text { memory deficit in } \\
\text { one individual case }\end{array}$ \\
\hline 21 & $\begin{array}{l}\text { Kardiasmeno } \\
\text { s et al. (2008) } \\
\text { USA }\end{array}$ & $\begin{array}{l}24 \\
\text { (Healthy } \\
\text { Control= } \\
24)\end{array}$ & 46 & $\begin{array}{l}M=44.4 \\
S D=8.2\end{array}$ & $\begin{array}{l}M=15.0 \\
S D=2.0\end{array}$ & $\begin{array}{l}\text { Not } \\
\text { Reported }\end{array}$ & $\begin{array}{l}\mathrm{RR}=8 \\
\mathrm{SP}=6\end{array}$ & Virtual Week & $\begin{array}{l}\text { Face to face } \\
\text { administration } \\
\text { at one time } \\
\text { point }\end{array}$ & $\begin{array}{l}\text { To compare PM } \\
\text { between MS and } \\
\text { controls, and as an } \\
\text { outcome measure } \\
\text { to evaluate the } \\
\text { effect of an } \\
\text { implementation- } \\
\text { intentions strategy } \\
\text { on PM }\end{array}$ \\
\hline
\end{tabular}




\begin{tabular}{|c|c|c|c|c|c|c|c|c|c|c|}
\hline \multirow{2}{*}{$\begin{array}{c}\text { Paper } \\
\#\end{array}$} & \multirow{2}{*}{$\begin{array}{l}\text { Author / } \\
\text { Year / } \\
\text { Country }\end{array}$} & \multicolumn{6}{|c|}{ MS group } & \multirow[b]{2}{*}{ EM Measure(s) } & \multicolumn{2}{|c|}{ Use of Measure } \\
\hline & & Sample Size & $\begin{array}{l}\text { Gender } \\
\text { (\%F) }\end{array}$ & Age (years) & $\begin{array}{l}\text { Education } \\
\text { (years) }\end{array}$ & Ethnicity & MS Type & & $\begin{array}{l}\text { How } \\
\text { Administered }\end{array}$ & Why used \\
\hline 22 & $\begin{array}{l}\text { Demers et al. } \\
\text { (2011) } \\
\text { Canada }\end{array}$ & $\begin{array}{l}30 \\
\text { (Healthy } \\
\text { Control= } \\
24)\end{array}$ & 67 & $\begin{array}{l}\text { MS Mild } \\
M=45.9 \\
S D=7.5 \\
\text { MS } \\
\text { Moderate/ } \\
\text { Severe } \\
M=44.3 \\
S D=8.5\end{array}$ & $\begin{array}{l}\text { MS Mild } \\
M=14.1 \\
S D=2.3 \\
M S \\
\text { Moderate/Se } \\
\text { vere } \\
M=13.2 \\
S D=2.6\end{array}$ & $\begin{array}{l}\text { Not } \\
\text { Reported }\end{array}$ & $\begin{array}{l}\text { MS Mild } \\
R R=8 \\
S P=3 \\
P P=3 \\
M S \\
\text { Moderate/Se } \\
\text { vere } \\
\text { RR=7 } \\
S P=7 \\
P P=2\end{array}$ & PRMQ & $\begin{array}{l}\text { Face to face } \\
\text { administration } \\
\text { in the lab or at } \\
\text { participants } \\
\text { home. } \\
\text { Administered at } \\
3 \text { time points } \\
\text { (90 minute } \\
\text { sessions) }\end{array}$ & $\begin{array}{l}\text { To correlate EM } \\
\text { with another } \\
\text { variable (mood) } \\
\text { and compare } \\
\text { across MS mild, MS } \\
\text { moderate/severe } \\
\text { cognitive deficit } \\
\text { and control groups }\end{array}$ \\
\hline 23 & $\begin{array}{l}\text { Dagenais et } \\
\text { al. (2013) } \\
\text { Canada }\end{array}$ & 41 & 70 & $\begin{array}{l}M=44.51 \\
S D=7.43\end{array}$ & $\begin{array}{l}\text { High } \\
\text { school=12 } \\
\text { College=8 } \\
\text { University=2 } \\
1\end{array}$ & $\begin{array}{l}\text { Not } \\
\text { Reported }\end{array}$ & $\begin{array}{l}\mathrm{RR}=35 \\
\mathrm{SP}=6\end{array}$ & MSNQ & $\begin{array}{l}\text { Face to face } \\
\text { inferred. } \\
\text { Administered at } \\
\text { one time point }\end{array}$ & $\begin{array}{l}\text { To correlate } \\
\text { patient and } \\
\text { informant EM with } \\
\text { other variables } \\
\text { (objective memory, } \\
\text { mood and } \\
\text { executive function) } \\
\text { and to evaluate the } \\
\text { concurrent validity } \\
\text { of a cognitive } \\
\text { screening test }\end{array}$ \\
\hline 24 & $\begin{array}{l}\text { Cutajar et al. } \\
(2000)\end{array}$ & 40 & 70 & $\begin{array}{l}M=38.67 \\
S D=+/-7.44\end{array}$ & Not Reporte & Not & $\mathrm{RR}=40$ & RBMT & $\begin{array}{l}\text { Face to face } \\
\text { inferred. }\end{array}$ & $\begin{array}{l}\text { To correlate EM } \\
\text { with other }\end{array}$ \\
\hline
\end{tabular}




\begin{tabular}{|c|c|c|c|c|c|c|c|c|c|c|}
\hline \multirow{2}{*}{$\begin{array}{c}\text { Paper } \\
\#\end{array}$} & \multirow{2}{*}{$\begin{array}{l}\text { Author / } \\
\text { Year / } \\
\text { Country }\end{array}$} & \multicolumn{6}{|c|}{ MS group } & \multirow[b]{2}{*}{ EM Measure(s) } & \multicolumn{2}{|c|}{ Use of Measure } \\
\hline & & Sample Size & $\begin{array}{l}\text { Gender } \\
\text { (\%F) }\end{array}$ & Age (years) & $\begin{array}{l}\text { Education } \\
\text { (years) }\end{array}$ & Ethnicity & MS Type & & $\begin{array}{l}\text { How } \\
\text { Administered }\end{array}$ & Why used \\
\hline & Italy & & & Range $=20-50$ & & & & & $\begin{array}{l}\text { Administered at } \\
4 \text { time points } \\
\text { (one every } 9 \\
\text { months) }\end{array}$ & $\begin{array}{l}\text { variables (QoL, } \\
\text { mood and frontal } \\
\text { lobe function) }\end{array}$ \\
\hline 25 & $\begin{array}{l}\text { Kujala et al. } \\
\text { (1996) } \\
\text { Finland }\end{array}$ & $\begin{array}{l}45 \\
\text { (Healthy } \\
\text { Control= } \\
35 \text { ) }\end{array}$ & $\begin{array}{l}\text { Cognitiv } \\
\text { ely } \\
\text { Preserve } \\
d=52.2 \\
\text { Cognitiv } \\
\text { e } \\
\text { Decline= } \\
50\end{array}$ & $\begin{array}{l}\text { Cognitively } \\
\text { Preserved: } \\
M=43.3 \\
S D=8.7 \\
\text { Cognitive } \\
\text { Decline: } \\
M=43.3 \\
S D=7.2\end{array}$ & $\begin{array}{l}\text { Cognitively } \\
\text { Preserved: } \\
M=11.6 \\
S D=3.5 \\
\text { Cognitive } \\
\text { Decline: } \\
M=11 \\
S D=2.9\end{array}$ & $\begin{array}{l}\text { Not } \\
\text { Reported }\end{array}$ & $\begin{array}{l}\text { Cognitively } \\
\text { Preserved: } \\
\mathrm{RR}=11 \\
\mathrm{CP}=9 \\
\mathrm{SP}=3 \\
\text { Cognitive } \\
\text { Decline: } \\
\mathrm{RR}=6 \\
\mathrm{CP}=13 \\
\mathrm{SP}=3\end{array}$ & $\begin{array}{l}\text { Measure of self- } \\
\text { evaluation of } \\
\text { everyday } \\
\text { memory and } \\
\text { learning }\end{array}$ & $\begin{array}{l}\text { Self- } \\
\text { administered at } \\
\text { one time point }\end{array}$ & $\begin{array}{l}\text { To compare the } \\
\text { pattern of memory } \\
\text { and learning } \\
\text { deficits between } \\
\text { MS cognitively } \\
\text { declined, MS } \\
\text { cognitively } \\
\text { preserved and } \\
\text { control groups, and } \\
\text { to compare with } \\
\text { other cognitive } \\
\text { tests (objective } \\
\text { memory) }\end{array}$ \\
\hline 26 & $\begin{array}{l}\text { Campbell et } \\
\text { al. (2016) } \\
\text { UK }\end{array}$ & 62 & 69 & $\begin{array}{l}\mathrm{M}=49.35 \\
\mathrm{SD}=8.88 \\
\text { Range=31-63 }\end{array}$ & $\begin{array}{l}\text { Normal } \\
\text { cognitive } \\
\text { performance } \\
M=14.05 \\
S D=2.34\end{array}$ & $\begin{array}{l}\text { Not } \\
\text { Reported }\end{array}$ & $\begin{array}{l}\mathrm{RR}=44 \\
\mathrm{SP}=18\end{array}$ & MSNQ & $\begin{array}{l}\text { Face to face } \\
\text { inferred. } \\
\text { Administration } \\
\text { at one time } \\
\text { point }\end{array}$ & $\begin{array}{l}\text { Part of a battery of } \\
\text { questionnaires to } \\
\text { compare QoL, } \\
\text { behaviour and } \\
\text { subjective } \\
\text { impairment }\end{array}$ \\
\hline
\end{tabular}




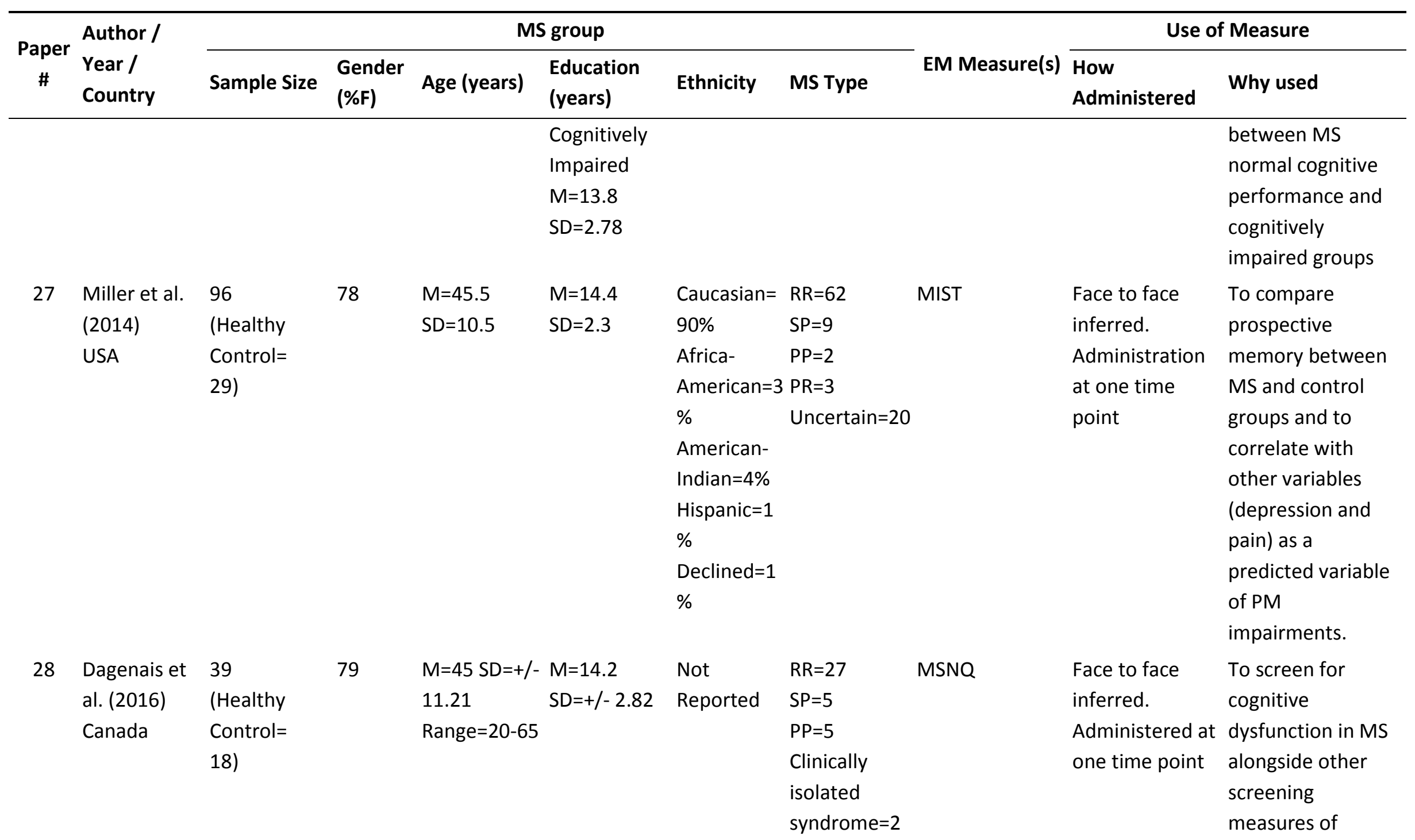




\begin{tabular}{|c|c|c|c|c|c|c|c|c|c|c|}
\hline \multirow{2}{*}{$\begin{array}{c}\text { Paper } \\
\#\end{array}$} & \multirow{2}{*}{$\begin{array}{l}\text { Author / } \\
\text { Year / } \\
\text { Country }\end{array}$} & \multicolumn{6}{|c|}{ MS group } & \multirow[b]{2}{*}{ EM Measure(s) } & \multicolumn{2}{|c|}{ Use of Measure } \\
\hline & & Sample Size & $\begin{array}{l}\text { Gender } \\
\text { (\%F) }\end{array}$ & Age (years) & $\begin{array}{l}\text { Education } \\
\text { (years) }\end{array}$ & Ethnicity & MS Type & & $\begin{array}{l}\text { How } \\
\text { Administered }\end{array}$ & Why used \\
\hline & & & & & & & & & & $\begin{array}{l}\text { cognition, anxiety } \\
\text { and depression }\end{array}$ \\
\hline 29 & $\begin{array}{l}\text { Moradi et al. } \\
\text { (2016) } \\
\text { Iran }\end{array}$ & $\begin{array}{l}200 \\
\text { (Healthy } \\
\text { Control= } \\
100)\end{array}$ & $\begin{array}{l}\text { Not } \\
\text { Reporte } \\
\text { d }\end{array}$ & $\begin{array}{l}\mathrm{M}=37.96 \\
\mathrm{SD}=9.12 \\
\text { Range }=22-53\end{array}$ & Not Reportec & $\begin{array}{l}\text { Not } \\
\text { Reported }\end{array}$ & Not Reported & PRMQ & $\begin{array}{l}\text { Administration } \\
\text { method not } \\
\text { reported }\end{array}$ & $\begin{array}{l}\text { To compare } \\
\text { cognitive } \\
\text { performance } \\
\text { between MS and } \\
\text { control groups } \\
\text { alongside } \\
\text { measures of } \\
\text { autobiographical } \\
\text { memory and } \\
\text { working memory }\end{array}$ \\
\hline 30 & $\begin{array}{l}\text { Sonder et al. } \\
\text { (2012) } \\
\text { The } \\
\text { Netherlands }\end{array}$ & $\begin{array}{l}121 \\
\text { (informants= } \\
121 \text { ) }\end{array}$ & 62 & $\begin{array}{l}\text { Median=53 } \\
\mathrm{IQR}=45-63\end{array}$ & $\begin{array}{l}\text { High } \\
\text { education } \\
\text { (College/Unis } \\
\text { ersity)=37 } \\
\text { Moderate } \\
\text { education } \\
\text { (Secondary } \\
\text { school)=40 } \\
\text { Low } \\
\text { education }\end{array}$ & $\begin{array}{l}\text { Not } \\
\text { Reported }\end{array}$ & $\begin{array}{l}\mathrm{RR}=43 \\
\mathrm{SP}=40 \\
\mathrm{PP}=34 \\
\text { Clinically } \\
\text { isolated } \\
\text { syndrome }=4\end{array}$ & $\begin{array}{l}\text { MSNQ-P MSNQ- } \\
\text { I (Dutch } \\
\text { translation) }\end{array}$ & $\begin{array}{l}\text { Self- } \\
\text { administered } \\
\text { and postal } \\
\text { administered }\end{array}$ & $\begin{array}{l}\text { To investigate } \\
\text { psychometric } \\
\text { properties and } \\
\text { determine the } \\
\text { interpretability } \\
\text { (the degree to } \\
\text { which one can } \\
\text { assign qualitative } \\
\text { meaning to } \\
\text { quantitative } \\
\text { scores) of a Dutch }\end{array}$ \\
\hline
\end{tabular}




\begin{tabular}{|c|c|c|c|c|c|c|c|c|c|c|}
\hline \multirow{2}{*}{$\begin{array}{c}\text { Paper } \\
\#\end{array}$} & \multirow{2}{*}{$\begin{array}{l}\text { Author / } \\
\text { Year / } \\
\text { Country }\end{array}$} & \multicolumn{6}{|c|}{ MS group } & \multirow[b]{2}{*}{ EM Measure(s) } & \multicolumn{2}{|c|}{ Use of Measure } \\
\hline & & Sample Size & $\begin{array}{l}\text { Gender } \\
\text { (\%F) }\end{array}$ & Age (years) & $\begin{array}{l}\text { Education } \\
\text { (years) }\end{array}$ & Ethnicity & MS Type & & $\begin{array}{l}\text { How } \\
\text { Administered }\end{array}$ & Why used \\
\hline \multirow{8}{*}{31} & & & & & $\begin{array}{l}\text { (Primary } \\
\text { school) }=42\end{array}$ & & & & & $\begin{array}{l}\text { translation and } \\
\text { correlate it with } \\
\text { measures of } \\
\text { anxiety and } \\
\text { depression, } \\
\text { cognition and } \\
\text { disability }\end{array}$ \\
\hline & $\begin{array}{l}\text { Mäntynen et } \\
\text { al. (2014) }\end{array}$ & 102 & 78 & $\begin{array}{l}\text { Intervention } \\
\text { group }\end{array}$ & $\begin{array}{l}\text { Intervention } \\
\text { group }\end{array}$ & $\begin{array}{l}\text { Not } \\
\text { Reported }\end{array}$ & $\mathrm{RR}=102$ & PDQ & $\begin{array}{l}\text { Face to face } \\
\text { inferred. }\end{array}$ & $\begin{array}{l}\text { PDQ: one of three } \\
\text { primary outcome }\end{array}$ \\
\hline & Finland* & & & $M=43.5$ & $M=13.6$ & & & MSNQ-P MSNQ- & Administered at & measures to \\
\hline & & & & $S D=8.7$ & $S D=2.3$ & & & 1 & 3 time points ( & compare between \\
\hline & & & & Control & Control & & & & baseline, after 3 & MS and control \\
\hline & & & & group & group & & & & months and & groups. \\
\hline & & & & $M=44.1$ & $M=13.8$ & & & & after 6 months) & MSNQ-P and \\
\hline & & & & $S D=8.8$ & $S D=2.6$ & & & & & $\begin{array}{l}\text { MSNQ-I: one of } \\
\text { eleven secondary } \\
\text { outcome measures } \\
\text { to compare } \\
\text { between MS and } \\
\text { control. }\end{array}$ \\
\hline 32 & $\begin{array}{l}\text { Rosti- } \\
\text { Otajärvi et al. } \\
(2013)\end{array}$ & 78 & 79 & $\begin{array}{l}\text { Intervention } \\
\text { group }\end{array}$ & $\begin{array}{l}\text { Intervention } \\
\text { group }\end{array}$ & $\begin{array}{l}\text { Not } \\
\text { Reported }\end{array}$ & $\mathrm{RR}=78$ & $\begin{array}{l}\text { PDQ } \\
\text { MSNQ-P MSNQ- } \\
\text { I }\end{array}$ & $\begin{array}{l}\text { Face to face } \\
\text { inferred. }\end{array}$ & $\begin{array}{l}\text { PDQ: one of three } \\
\text { primary outcome } \\
\text { measures to }\end{array}$ \\
\hline
\end{tabular}




\begin{tabular}{|c|c|c|c|c|c|c|c|c|c|}
\hline \multirow{2}{*}{$\begin{array}{c}\text { Paper } \\
\#\end{array}$} & \multirow{2}{*}{$\begin{array}{l}\text { Author / } \\
\text { Year / } \\
\text { Country }\end{array}$} & \multicolumn{5}{|c|}{ MS group } & \multirow[b]{2}{*}{ EM Measure(s) } & \multicolumn{2}{|c|}{ Use of Measure } \\
\hline & & Sample Size & $\begin{array}{l}\text { Gender } \\
\text { (\%F) }\end{array}$ & Age (years) & $\begin{array}{l}\text { Education } \\
\text { (years) }\end{array}$ & Ethnicity & & $\begin{array}{l}\text { How } \\
\text { Administered }\end{array}$ & Why used \\
\hline & Finland* & & & $\begin{array}{l}\mathrm{M}=43.7 \\
\mathrm{SD}=8.7 \\
\text { Control } \\
\text { group } \\
\mathrm{M}=45.5 \\
\mathrm{SD}=9.4\end{array}$ & $\begin{array}{l}\mathrm{M}=13.5 \\
\mathrm{SD}=2.4 \\
\text { Control } \\
\text { group } \\
\mathrm{M}=13.4 \\
\mathrm{SD}=2.6\end{array}$ & & & $\begin{array}{l}\text { Administered at } \\
\text { I year follow-up }\end{array}$ & $\begin{array}{l}\text { compare between } \\
\text { MS and control } \\
\text { groups across four } \\
\text { time points. } \\
\text { MSNQ-P and } \\
\text { MSNQ-I: one of } \\
\text { eleven secondary } \\
\text { outcome measures } \\
\text { to compare } \\
\text { between MS and } \\
\text { control groups and } \\
\text { to compare across } \\
\text { four time points. }\end{array}$ \\
\hline 33 & $\begin{array}{l}\text { Shevil and } \\
\text { Finlayson } \\
\text { (2010) } \\
\text { USA }\end{array}$ & 35 & 74.3 & $\begin{array}{l}\mathrm{M}=52.4 \\
\mathrm{SD}=10.3 \\
\text { Range=26-70 }\end{array}$ & $\begin{array}{l}<12 \text { yrs }=3 \\
13-15 y r s=13 \\
>15 y r s=19\end{array}$ & $\begin{array}{l}\text { Caucasian= } \\
80 \% \\
\text { African- } \\
\text { American=1 } \\
4.3 \% \\
\text { Other }=5.7 \%\end{array}$ & Not Reported MSNQ & $\begin{array}{l}\text { Telephone } \\
\text { administered at } \\
\text { one time point. }\end{array}$ & $\begin{array}{l}\text { As a phase } 1 \\
\text { screening measure } \\
\text { for eligibility } \\
\text { (included if score } \\
\text { was } \geq 23 \text { ) alongside } \\
\text { other screening } \\
\text { measures of } \\
\text { fatigue and } \\
\text { depression. It was } \\
\text { supplemented by }\end{array}$ \\
\hline
\end{tabular}




\begin{tabular}{|c|c|c|c|c|c|c|c|c|c|c|}
\hline \multirow{2}{*}{$\begin{array}{l}\text { Paper } \\
\#\end{array}$} & \multirow{2}{*}{$\begin{array}{l}\text { Author / } \\
\text { Year / } \\
\text { Country }\end{array}$} & \multicolumn{6}{|c|}{ MS group } & \multicolumn{3}{|c|}{ Use of Measure } \\
\hline & & Sample Size & $\begin{array}{l}\text { Gender } \\
\text { (\%F) }\end{array}$ & Age (years) & $\begin{array}{l}\text { Education } \\
\text { (years) }\end{array}$ & Ethnicity & MS Type & EM Measure(s) & $\begin{array}{l}\text { How } \\
\text { Administered }\end{array}$ & Why used \\
\hline \multirow[b]{2}{*}{34} & & & & & & & & & & $\begin{array}{l}\text { an objective } \\
\text { screening battery } \\
\text { (phase } 2 \text { screening) }\end{array}$ \\
\hline & $\begin{array}{l}\text { Benedict et } \\
\text { al. (2008) } \\
\text { USA }\end{array}$ & $\begin{array}{l}76 \\
\text { (Healthy } \\
\text { Control= } \\
25)\end{array}$ & 74 & $\begin{array}{l}M=47.6 \\
S D=+/-8.4\end{array}$ & $\begin{array}{l}M=14.7 \\
S D=+/-2.2\end{array}$ & $\begin{array}{l}\text { Caucasian= } \\
91 \% \\
\text { Not } \\
\text { Reported=9 } \\
\%\end{array}$ & $\begin{array}{l}\mathrm{RR}=63 \\
\mathrm{SP}=11 \\
\mathrm{PP}=2\end{array}$ & MSNQ & $\begin{array}{l}\text { Administered } \\
\text { face to face at } \\
\text { monthly } \\
\text { intervals for } 6 \\
\text { months } \\
\text { following initial } \\
\text { evaluation. }\end{array}$ & $\begin{array}{l}\text { To investigate } \\
\text { reliability as a } \\
\text { screening measure } \\
\text { at monthly } \\
\text { intervals. To } \\
\text { compare between } \\
\text { MS and control } \\
\text { groups, to compare } \\
\text { correlations } \\
\text { between each time } \\
\text { point and as a } \\
\text { predicted variable } \\
\text { across each time } \\
\text { point by measures } \\
\text { of cognition and } \\
\text { depression }\end{array}$ \\
\hline 35 & $\begin{array}{l}\text { Carone et al. } \\
(2005)\end{array}$ & $\begin{array}{l}122 \\
\text { (informants= }\end{array}$ & 72 & $\mathrm{M}=44 \mathrm{SD}=8.8$ & $\begin{array}{l}M=14.5 \\
S D=2.1\end{array}$ & $\begin{array}{l}\text { Caucasian= } \\
92 \%\end{array}$ & $\begin{array}{l}\mathrm{RR}=88 \\
\mathrm{SP}=30\end{array}$ & MSNQ & $\begin{array}{l}\text { Face to face } \\
\text { inferred. }\end{array}$ & $\begin{array}{l}\text { To compare } \\
\text { discrepancy scores }\end{array}$ \\
\hline & USA & $\begin{array}{l}\text { 122) (Healthy } \\
\text { Control= }\end{array}$ & & & & & $\begin{array}{l}P P=2 \\
R P=2\end{array}$ & & $\begin{array}{l}\text { Administered at } \\
\text { one time point }\end{array}$ & $\begin{array}{l}\text { between MS (and } \\
\text { informants) and }\end{array}$ \\
\hline
\end{tabular}




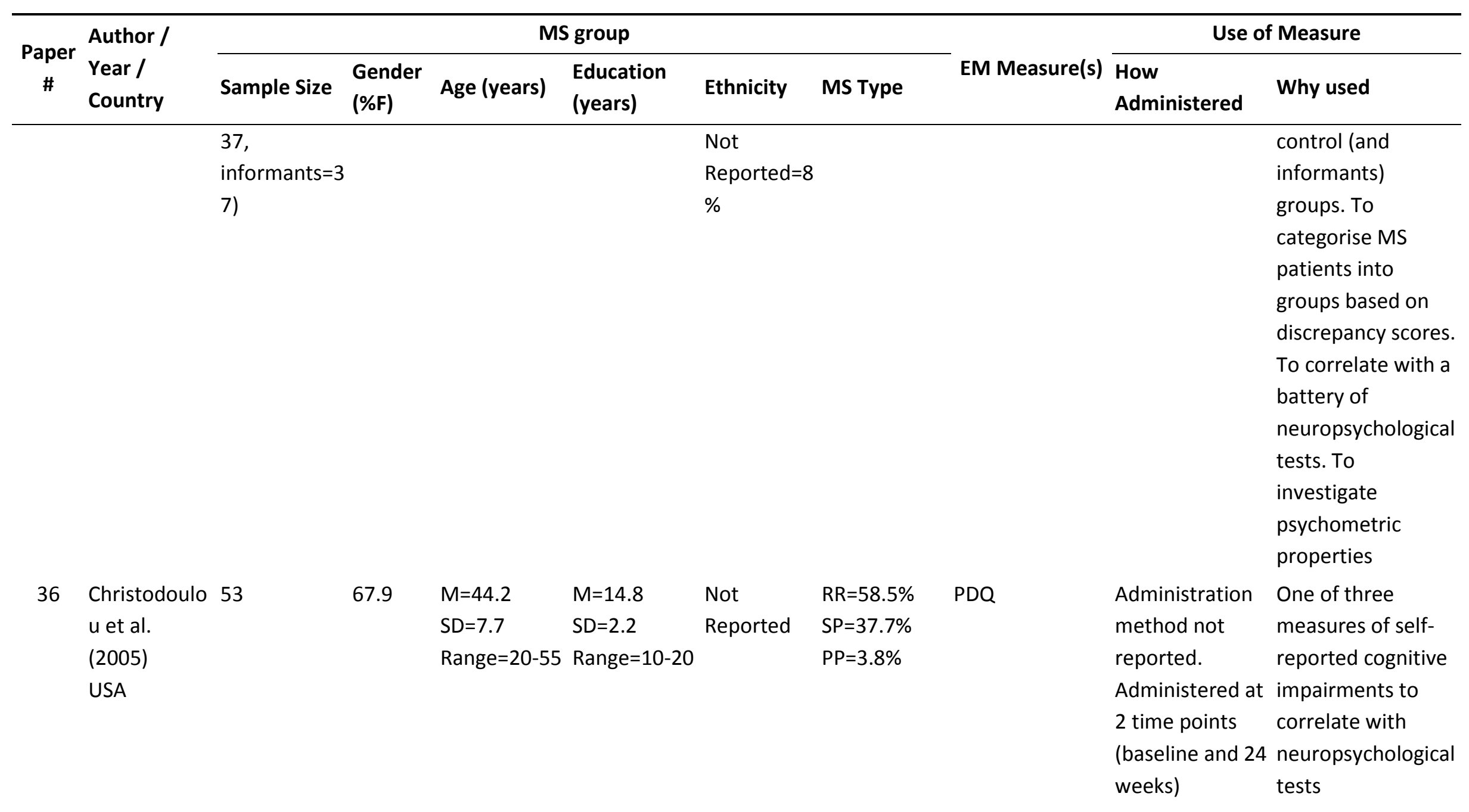




\begin{tabular}{|c|c|c|c|c|c|c|c|c|c|c|}
\hline \multirow{2}{*}{$\begin{array}{c}\text { Paper } \\
\#\end{array}$} & \multirow{2}{*}{$\begin{array}{l}\text { Author / } \\
\text { Year / } \\
\text { Country }\end{array}$} & \multicolumn{6}{|c|}{ MS group } & \multirow[b]{2}{*}{ EM Measure(s) } & \multicolumn{2}{|c|}{ Use of Measure } \\
\hline & & Sample Size & $\begin{array}{l}\text { Gender } \\
\text { (\%F) }\end{array}$ & Age (years) & $\begin{array}{l}\text { Education } \\
\text { (years) }\end{array}$ & Ethnicity & MS Type & & $\begin{array}{l}\text { How } \\
\text { Administered }\end{array}$ & Why used \\
\hline 37 & $\begin{array}{l}\text { O'Brien et al. } \\
\text { (2007) } \\
\text { USA }\end{array}$ & $\begin{array}{l}48 \\
\text { (informants= } \\
48 \text { ) (Healthy } \\
\text { Control= } \\
40, \\
\text { informants=4 } \\
\text { 0) }\end{array}$ & 80 & $\begin{array}{l}\mathrm{M}=45.1 \\
\mathrm{SD}=9.1 \\
\text { Range=27-56 }\end{array}$ & $\begin{array}{l}M=14.7 \\
S D=2.1\end{array}$ & $\begin{array}{l}\text { Not } \\
\text { Reported }\end{array}$ & $\begin{array}{l}\mathrm{RR}=68.8 \% \\
\mathrm{PP}=10 \% \\
\mathrm{SP}=21.2 \%\end{array}$ & $\begin{array}{l}\text { MSNQ-S } \\
\text { MSNQ-I }\end{array}$ & $\begin{array}{l}\text { Face to face } \\
\text { inferred. } \\
\text { Administered at } \\
\text { one time point }\end{array}$ & $\begin{array}{l}\text { To compare scores } \\
\text { between MS and } \\
\text { healthy control } \\
\text { groups. To } \\
\text { correlate with } \\
\text { other variables } \\
\text { (neuropsychol } \\
\text { ogical functioning, } \\
\text { mood and daily } \\
\text { functioning). As a } \\
\text { predictor variable } \\
\text { of daily functioning } \\
\text { and } \\
\text { neuropsychological } \\
\text { functioning. } \\
\text { To determine its } \\
\text { sensitivity and } \\
\text { specificity }\end{array}$ \\
\hline 38 & $\begin{array}{l}\text { Samartzis et } \\
\text { al. (2014) } \\
\text { Greece }\end{array}$ & 100 & 64 & $\begin{array}{l}M=40.5 \\
S D=+/-10.3\end{array}$ & $\begin{array}{l}\text { Primary } \\
\text { Education=1 } \\
9 \%\end{array}$ & $\begin{array}{l}\text { Not } \\
\text { Reported }\end{array}$ & Not Reporte & $P D Q$ & $\begin{array}{l}\text { Self- } \\
\text { administered at } \\
\text { one time point }\end{array}$ & $\begin{array}{l}\text { To correlate with } \\
\text { another variable } \\
\text { (depression) and as } \\
\text { a predictor variable } \\
\text { for QoL }\end{array}$ \\
\hline
\end{tabular}




\begin{tabular}{|c|c|c|c|c|c|c|c|c|c|c|}
\hline \multirow{2}{*}{$\begin{array}{c}\text { Paper } \\
\#\end{array}$} & \multirow{2}{*}{$\begin{array}{l}\text { Author / } \\
\text { Year / } \\
\text { Country }\end{array}$} & \multicolumn{6}{|c|}{ MS group } & \multicolumn{3}{|c|}{ Use of Measure } \\
\hline & & Sample Size & $\begin{array}{l}\text { Gender } \\
\text { (\%F) }\end{array}$ & Age (years) & $\begin{array}{l}\text { Education } \\
\text { (years) }\end{array}$ & Ethnicity & MS Type & EM Measure(s) & $\begin{array}{l}\text { How } \\
\text { Administered }\end{array}$ & Why used \\
\hline & & & & & $\begin{array}{l}\text { Secondary } \\
\text { Education=5 } \\
7 \% \\
\text { Tertiary } \\
\text { Education=2 } \\
4 \%\end{array}$ & & & & & \\
\hline 39 & $\begin{array}{l}\text { Lovera et al. } \\
(2006) \\
\text { USA }\end{array}$ & 49 & 76 & $\begin{array}{l}M=49.3 \\
S D=+/-7.6\end{array}$ & Not Reported & $\begin{array}{l}\text { Caucasian= } \\
94 \% \\
\text { African- } \\
\text { American=1 } \\
\% \\
\text { Other } \\
\text { (except } \\
\text { Asian or } \\
\text { Pacific } \\
\text { Islander, } \\
\text { Native } \\
\text { American } \\
\text { or } \\
\text { Hispanic)=2 } \\
\%\end{array}$ & $\begin{array}{l}\mathrm{RR}=32 \\
\mathrm{SP}=15 \\
\mathrm{PP}=2\end{array}$ & PDQ & $\begin{array}{l}\text { Postal } \\
\text { administered at } \\
\text { one time point }\end{array}$ & $\begin{array}{l}\text { To correlate with } \\
\text { two measures of } \\
\text { cognitive } \\
\text { impairment and } \\
\text { one measure of } \\
\text { depression }\end{array}$ \\
\hline
\end{tabular}




\begin{tabular}{|c|c|c|c|c|c|c|c|c|c|c|}
\hline \multirow{2}{*}{$\begin{array}{c}\text { Paper } \\
\#\end{array}$} & \multirow{2}{*}{$\begin{array}{l}\text { Author / } \\
\text { Year / } \\
\text { Country }\end{array}$} & \multicolumn{6}{|c|}{ MS group } & \multirow[b]{2}{*}{ EM Measure(s) } & \multicolumn{2}{|c|}{ Use of Measure } \\
\hline & & Sample Size & $\begin{array}{l}\text { Gender } \\
\text { (\%F) }\end{array}$ & Age (years) & $\begin{array}{l}\text { Education } \\
\text { (years) }\end{array}$ & Ethnicity & MS Type & & $\begin{array}{l}\text { How } \\
\text { Administered }\end{array}$ & Why used \\
\hline 40 & $\begin{array}{l}\text { Pérez-Martín } \\
\text { et al. (2017) } \\
\text { Spain* }\end{array}$ & & 52 & $\begin{array}{l}\text { Treatment } \\
\text { Group: } \\
M=44.93 \\
S D=+/-9.89 \\
\text { Control } \\
\text { Group: } \\
M=40.88 \\
S D=+/-8.5\end{array}$ & $\begin{array}{l}\text { Treatment } \\
\text { Group: } \\
\mathrm{M}=10.21 \\
\mathrm{SD}=+/-2.64 \\
\text { Control } \\
\text { Group: } \\
\mathrm{M}=11.59 \\
\mathrm{SD}=+/-3.03\end{array}$ & $\begin{array}{l}\text { Not } \\
\text { Reported }\end{array}$ & $\begin{array}{l}\mathrm{RR}=57 \\
\mathrm{SP}=2 \\
\mathrm{PP}=3\end{array}$ & MSNQ & $\begin{array}{l}\text { Face to face at } 2 \\
\text { time points } \\
\text { (baseline and at } \\
3 \text { months post } \\
\text { intervention) }\end{array}$ & $\begin{array}{l}\text { To compare scores } \\
\text { between treatment } \\
\text { and control groups } \\
\text { alongside a battery } \\
\text { of } \\
\text { neuropsychological } \\
\text { tests and other } \\
\text { questionnaires } \\
\text { (anxiety and } \\
\text { depression, fatigue } \\
\text { and QoL) at } \\
\text { baseline and } 3 \\
\text { months post } \\
\text { intervention }\end{array}$ \\
\hline 41 & $\begin{array}{l}\text { Strober et al. } \\
(2016) \\
\text { USA }\end{array}$ & 70 & 81 & $\begin{array}{l}M=48.97 \\
S D=9.26\end{array}$ & $\begin{array}{l}M=15.5 \\
S D=2.47\end{array}$ & $\begin{array}{l}\text { Not } \\
\text { Reported }\end{array}$ & $\begin{array}{l}R R=52 \\
P P=4 \\
S P=13 \\
P R=1\end{array}$ & PDQ & $\begin{array}{l}\text { Administration } \\
\text { method not } \\
\text { reported. } \\
\text { Administered at } \\
\text { one time point. }\end{array}$ & $\begin{array}{l}\text { To correlate } \\
\text { subjective } \\
\text { cognitive concerns } \\
\text { with a battery of } \\
\text { objective } \\
\text { neuropsychological } \\
\text { tests. To correlate } \\
\text { with other } \\
\text { variables of }\end{array}$ \\
\hline
\end{tabular}




\begin{tabular}{|c|c|c|c|c|c|c|c|c|c|c|}
\hline \multirow{2}{*}{$\begin{array}{c}\text { Paper } \\
\#\end{array}$} & \multirow{2}{*}{$\begin{array}{l}\text { Author / } \\
\text { Year / } \\
\text { Country }\end{array}$} & \multicolumn{6}{|c|}{ MS group } & \multirow[b]{2}{*}{ EM Measure(s) } & \multicolumn{2}{|c|}{ Use of Measure } \\
\hline & & Sample Size & $\begin{array}{l}\text { Gender } \\
\text { (\%F) }\end{array}$ & Age (years) & $\begin{array}{l}\text { Education } \\
\text { (years) }\end{array}$ & Ethnicity & MS Type & & $\begin{array}{l}\text { How } \\
\text { Administered }\end{array}$ & Why used \\
\hline & & & & & & & & & & $\begin{array}{l}\text { psychological } \\
\text { heath (depression, } \\
\text { anxiety, fatigue } \\
\text { and self-efficacy) }\end{array}$ \\
\hline 42 & $\begin{array}{l}\text { Walker et al. } \\
\text { (2016) } \\
\text { Canada }\end{array}$ & $\begin{array}{l}57 \\
\text { (Healthy } \\
\text { Control= } \\
51 \text { ) }\end{array}$ & 72 & $\begin{array}{l}\mathrm{M}=45.44 \\
\mathrm{SD}=9.93 \\
\text { Range }=18-59\end{array}$ & $\begin{array}{l}M=15.44 \\
S D=2.68\end{array}$ & $\begin{array}{l}\text { Not } \\
\text { Reported }\end{array}$ & $\begin{array}{l}\mathrm{RR}=44 \\
\mathrm{SP}=9 \\
\mathrm{PP}=4\end{array}$ & $\begin{array}{l}\text { MSNQ-S } \\
\text { MSNQ-I }\end{array}$ & $\begin{array}{l}\text { Face to face } \\
\text { inferred at } 2 \\
\text { time points } \\
\text { (baseline and } \\
\text { follow-up } \\
\text { session (one to } \\
\text { three weeks } \\
\text { later)) }\end{array}$ & $\begin{array}{l}\text { To compare self } \\
\text { and informant } \\
\text { reported cognition } \\
\text { between MS and } \\
\text { control group at } \\
\text { baseline and follow } \\
\text { up session. To } \\
\text { correlate with a } \\
\text { cognitive } \\
\text { assessment at } \\
\text { baseline and at } \\
\text { follow-up and with } \\
\text { another variable } \\
\text { (depression) }\end{array}$ \\
\hline 43 & $\begin{array}{l}\text { Chiaravalloti } \\
\text { et al. (2005) } \\
\text { USA* }\end{array}$ & 28 & $\begin{array}{l}\text { Experim } \\
\text { ental } \\
\text { Group=6 }\end{array}$ & $\begin{array}{l}\text { Experimental } \\
\text { Group: } \\
M=45.14\end{array}$ & $\begin{array}{l}\text { Experimental } \\
\text { Group: } \\
M=14.64\end{array}$ & $\begin{array}{l}\text { Not } \\
\text { Reported }\end{array}$ & $\begin{array}{l}\mathrm{RR}=17 \\
\mathrm{PP}=4 \\
\mathrm{SP}=7\end{array}$ & MFQ & $\begin{array}{l}\text { Face to Face at } 3 \\
\text { time points } \\
\text { (baseline, } 6\end{array}$ & $\begin{array}{l}\text { As part of a } \\
\text { neuropsychological } \\
\text { assessment to }\end{array}$ \\
\hline & & & 4 & $S D=13.78$ & $S D=2.71$ & & & & $\begin{array}{l}\text { weeks and } 11 \\
\text { weeks) }\end{array}$ & $\begin{array}{l}\text { compare cognitive } \\
\text { functioning pre and }\end{array}$ \\
\hline
\end{tabular}




\begin{tabular}{|c|c|c|c|c|c|c|c|c|c|}
\hline \multirow{2}{*}{$\begin{array}{c}\text { Paper } \\
\#\end{array}$} & \multirow{2}{*}{$\begin{array}{l}\text { Author / } \\
\text { Year / } \\
\text { Country }\end{array}$} & \multicolumn{5}{|c|}{ MS group } & \multirow[b]{2}{*}{ EM Measure(s) } & \multicolumn{2}{|c|}{ Use of Measure } \\
\hline & & Sample Size & $\begin{array}{l}\text { Gender } \\
\text { (\%F) }\end{array}$ & Age (years) & $\begin{array}{l}\text { Education } \\
\text { (years) }\end{array}$ & Ethnicity & & $\begin{array}{l}\text { How } \\
\text { Administered }\end{array}$ & Why used \\
\hline & & & Control & Control & Control & & & & post treatment \\
\hline & & & Group $=5$ & Group: & Group: & & & & between \\
\hline & & & 7 & $M=46$ & $M=15.04$ & & & & experimental and \\
\hline & & & & $\mathrm{SD}=9.28$ & $\mathrm{SD}=2.82$ & & & & control groups \\
\hline \multirow[t]{4}{*}{44} & Sullivan et al. & 1180 & 72 & $M=49$ & $M=12.8$ & Not & Not Reported PDQ & Posted in a & To evaluate \\
\hline & $(1990)$ & (Healthy & & Range $=17-84$ & & Reported & & newsletter at & psychometric \\
\hline & Canada & Control= & & & & & & one time point. & properties \\
\hline & & 200) & & & & & & & \\
\hline
\end{tabular}

Note. Key: *RCTs: randomised control trials, ${ }^{\text {a: }}$ statistics include MS, TBI and stroke patients.

Abbreviations: CAMPROMPT: Cambridge Prospective Memory Test; CFQ: Cognitive Failures Questionnaire; EM: Everyday memory; EMQ: Everyday

Memory Questionnaire; IQR: interquartile range; M: Mean; MFQ: Memory Functioning Questionnaire; MIST: Memory for Intentions Screening Test; MRS:

Memory Rating Scale; MS: Multiple Sclerosis; MSNQ: MS Neuropsychological Questionnaire (MSNQ-P: patient self-report version; MSNQ-I: Informant

version); PDQ: Perceived Deficits Questionnaire; PP: primary progressive; PR: progressive-relapsing; PRMQ: Prospective and Retrospective Memory

Questionnaire; QoL: Quality of life; RBMT: Rivermead Behavioural Memory Test; RR: Relapsing-remitting; SD: Standard deviation; SP: secondary

progressive. 